Московкин Владимир Михайлович 1

доктор географических наук, директор Центра наукометрических исследований и развития университетской конкурентоспособности, профессор кафедры мировой экономики НИУ «БелГУ»

\section{Сунь Синюань ${ }^{1}$}

аспирант кафедры менеджмента организаций НИУ «БелГУ»

1 Белгородский государственный национальный исследовательский университет, Белгород, Россия

\title{
Рейтингование экономистов: современное состояние вопроса и перспективы дальнейших исследований
}

Показано, что расчет рейтингов ученых на основе стандартных показателей РИНЦ без привязывания этих показателей к журнальным публикациям является ошибочным, так как в этом случае обнаруживается чрезмерно большое число цитирований учебников и монографий, идущих из диссертаций и их авторефератов. Данный вывод сделан из расчетов по рейтингу Е.В. Балацкого за 2016 г. Формализована известная преступная схема накручивания цитируемости и индекса Хирша, которая использует две различные группы журналов, в одной из которых публикуются статьи иленов преступного оргкомитета конференций, а во второй журналь, используемые для накручивания ссылок иленов этого оргкомитета. Проделан сравнительный корреляиионно-регрессионный анализ рейтингов российских экономистов Е.В. Балацкого за 2015 и 2016 г2., который показал их плохую согласованность, ито говорит о значительных различиях в методологиях их расчетов.

Ключевъе слова: рейтинги ученых, рейтинги экономистов, РИНЦ, публикационная активность, цитируемость, индекс Хирша

\section{Введение}

0 чевидно, что интерес к рейтингованию ученых резко возрос после разработки Юджином Гарфильдом индекса цитируемости на основе базы данных по журнальным публикациям Института научной информации США [1]. В дальней- шем было разработано множество других метрик цитирования для авторов, например, большое семейство хиршеподобных метрик [2-4] (Hirsch, 2005; Waltman, 2012; Bornmann, 2011).

В последнее время эти метрики подвергались серьезной критике из за того, что они не удовлетворяют простейшим 
постулатам сравнения [2] (Hirsch, 2005). В качестве их альтернативы было предложено семейство метрик цитирования под названием Scoring Rule, которое удовлетворяет указанным постулатам сравнения за счёт учета всего спектра публикаций и цитирований автора [2,5] (Hirsch, 2005; Marchant, 2009). В развитие этого подхода в работах [6,7] (Moskovkin, 2014; Moskovkin, 2015) была предложена метрика цитирования IF-Scoring Rule, которая учитывает импакт-факторы журналов, в которых были опубликованы статьи автора, а также импакт-факторы журналов, из которых идут ссылки на его статьи.

Из небольшого количества статей, которые идентифицируются с помощью расширенного поиска в Google Scholar на запрос "рейтинги ученых», отметим работы [8-10] (Arzamastsev, 2008; Shtennikov, 2015; Kirvas, 2013). Например, в работе [8] (Arzamastsev, 2008) построен рейтинг для 23 профессоров Тамбовского государственного университета по запросам в поисковых системах Яндекс (http://yandex.ru) и Рамблер (http://rambler.ru).

Первой отечественной работой, в которой был построен обоснованный рейтинг экономистов, является работа И.Г. Дежиной и В.В. Дашкеева [11] (Dezhina, Dash$k e e v, 2008)$. В ней систематизированы публикации по 12-ти ведущим российским экономическим журналам за период с 2000 по 2007 год включительно (5300 авторов, 110000 статей) и идентифицирован список экономистов, имеющих не менее 11 публикаций (130 человек). Кроме того, проделан экспертный опрос и проведен подсчет зарубежных журнальных публикаций российских экономистов в базе данных RePEc (Research Papers in Economics).

В дальнейшем Е.В. Балацкий и Н.А. Екимова [12] (Balatskiy, Ekomova, 2015) разработали на основе статистики РИНЦ рейтинг академической активности и популярности (РААП), который был опубликован для ТОР-500 российских экономистов в 2015 г. на сайте авторского журнала Е.В. Балацкого «Неэргодическая экономика» [13].

В дальнейшем методология расчета этого рейтинга была усовершенствована, и в 2016 г. он был опубликован для ТОР500 российских экономистов под названием «Золотой рейтинг академической активности и популярности экономистов России» [14].

Анализ наукометрических показателей этого рейтинга (число публикаций, число цитирований, индекс Хирша) по последовательным выборкам в 100 человек показал на несбалансированность вышеуказанных показателей. Например, рост числа публикаций приводил к падению цитируемости и индекса Хирша [15]. Отсюда был сделан вывод, что в России сложился своеобразный синдром холостых публикаций, состоящий в том, что многие экономисты пишут и публикуют статьи, которые не содержат в себе новых результатов и не вызывают интереса со стороны научного сообщества.

В развитие работы [15] (Balatskiy, Yurievich, 2016) в статье А.В. Шумилова и Е.В. Балацкого [16] (Shumilov, Balatskiy, 2016) было детально изучено представление российских публикаций в базе данных RePEc. B ней было показано, что в начале 2010 г. в этой базе данных насчитывались 99 авторов из 32 российских организаций, а в апреле 2016 г. отмечался уже 941 автор из 118 организаций, представляющих 33 региона. Учитывались только те авторы, которые при регистрации подтвердили авторство хотя бы одной публикации из базы данных RePEc. Отметим, что на апрель 2016 г. в этой базе данных было более 2 млн документов, 1,2 млн статей из 2,4 тыс. журналов, 47 тыс. зарегистрированных авторов, 13,5 тыс. образовательных и исследовательских организаций [16] (Shumilov, Balatskiy, 2016).

титулованные ученье в верхней части рейтинга побеждают за счет огромного количества ссьлок на их монографии и учебники, идущзие, в основном, из диссертаций 


\section{традищия преимущественного}

цитирования определенного круга

титулованных ученьх идет еще с

советских времен

\section{Основные результаты \\ исследования}

Практики недобросовестного

цитирования с их отражением

в Российском индексе научного цитирования

E сли мы в Российском индексе научного цитирования (РИНЦ) построим ранжировку ученых в произвольной области знаний по агрегированному показателю, включающему в себя общие количества публикаций и цитирований вместе с индексом Хирша, то мы увидим, что титулованные ученые в верхней части рейтинга побеждают за счет огромного количества ссылок на их монографии и учебники, идущие, в основном, из диссертаций. Этот феномен мы обнаружили,

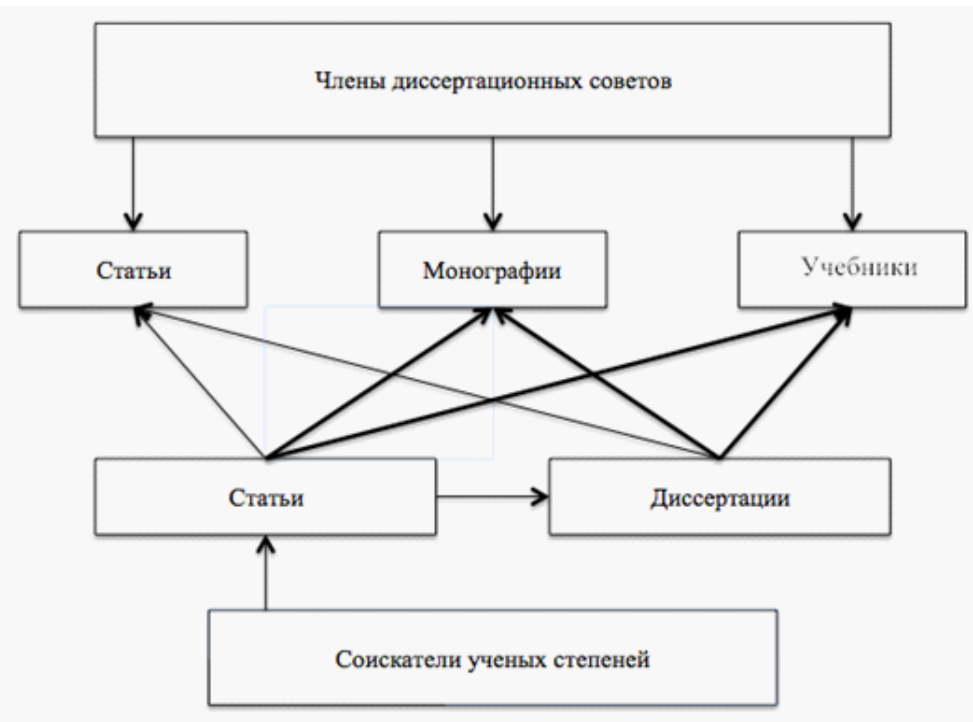

Рисунок 1.

Схема цитирования соискателями научных степеней работ членов специализированных ученых советов. детально рассматривая рейтинг ведущих экономистов России Е.В. Балацкого. Мы формализовали его на рисунке 1 , полагая, что титулованные ученые являются поголовно членами диссертационных советов. На этом рисунке вертикальные и горизонтальные стрелки соответствуют публикации научных статей, монографий, учебников и диссертаций, а наклонные их цитированиям.

Так сложилось, что соискатели ученых степеней, публикуя свои статьи и диссертации, в большей степени цитируют монографии и учебники членов диссертационных советов, чем их статьи. На рисунке это показано более жирными стрелками. В то же время в монографиях и учебниках аккумулировано ранее опубликованное в статьях новое научное знание, а научная этика требует ссылаться в первую очередь на первоисточники, в которых генерируется новое научное знание, а это статьи. В этой связи в индексах цитирования Web of Science и Scopus идет привязка исключительно к статьям, опубликованным в журналах с тем или иным импакт-фактором. Поэтому, при расчете рейтингов ученых с помощью РИНЦ необходимо привязываться к журнальным статьям. Отметим, что в авторских профилях РИНЦ предусмотрено вычленение из журнальных публикаций и их цитирований, но это же необходимо сделать и для индекса Хирша.

Традиция преимущественного цитирования определенного круга титулованных ученых идет еще с советских времен. В каждой научной дисциплине, по которой защищались диссертации, имелся ограниченный круг таких элитных учёных на монографии, учебники и статьи которых в обязательном порядке шли ссылки. Это было негласным правилом. Научные руководители и члены диссертационных советов обычно к этому не принуждали соискателей. Но последние, просматривая авторефераты диссертаций и сами диссертации, это всё воочию видели и считали своим долгом ссылаться на светил науки к месту или не к месту. Таким путем они пытались их как бы задобрить перед защитой своих диссертаций. Круг титулованных 
ученых в каждой научной дисциплине не был постоянным, а варьировал в зависимости от значимости конкурирующих школ или, как любили говорить, научных кланов. Часто вообще отсутствовало существенное перекрестное цитирование между членами различных жестко конкурирующих научных школ.

Итак, в каждой научной дисциплине действовали множество научных школ, часто привязанных к специализированным советам по защите докторских диссертаций и между которыми происходила жесткая конкуренция, которая сильно влияла на ландшафт цитирования в этих научных дисциплинах. Между научными школами существовала иерархия, когда менее значимые научные школы входили в более крупные. Мы пишем об этом в прошедшем времени, ссылаясь на советский опыт, так как после распада СССР произошло разрушение единой научной системы и большинства научных школ.

Следует особо отметить, что качество и фундаментальность научных исследований в целом в советское время были намного выше, чем сейчас. Не было гонки под лозунгом «Publish or Perish» за количеством публикаций и индексом Хирша, а было стремление опубликовать добротную статью в отечественном академическом или зарубежном солидном журнале.

Эта публикационная гонка доведена у нас до абсурда. Все уже привыкли к публикациям ученых социально-экономического и гуманитарного профилей в специально созданных для них «мусорных журналах», но примитивная жульническая схема, реализованная в Институте экспериментальной и теоретической биофизики РАН, буквально потрясла российскую научную общественность. Мы формализовали эту схему на рисунке 2 .

Полагаем, что эта и близкие к ней схемы широко используются в отечественной публикационной практике, о чем свидетельствует деятельность волонтерского проекта «Диссернет», благодаря которой был выявлен феномен «золотого треугольника» по производству фальшивых диссертаций с их относительно большим



Рисунок 2.

Преступная схема накручивания цитирований и индекса Хирша.

количеством в социально-экономических и гуманитарных областях знаний [17].

Проиллюстрируем схему, показанную на рисунке 1, данными из рейтинга Балацкого Е.В. за 2016 г. [14]. В таблице 1 мы привели исходные и наши расчетные данные по публикационной активности и цитируемости первой десятки экономистов

в советское время не было гонки под лозунгом «Publish or Perish» $3 a$ количеством публикаций и индексом Хириа, а было стремление опубликовать добротную статью в отечественном академическом или зарубежном солидном журнале 


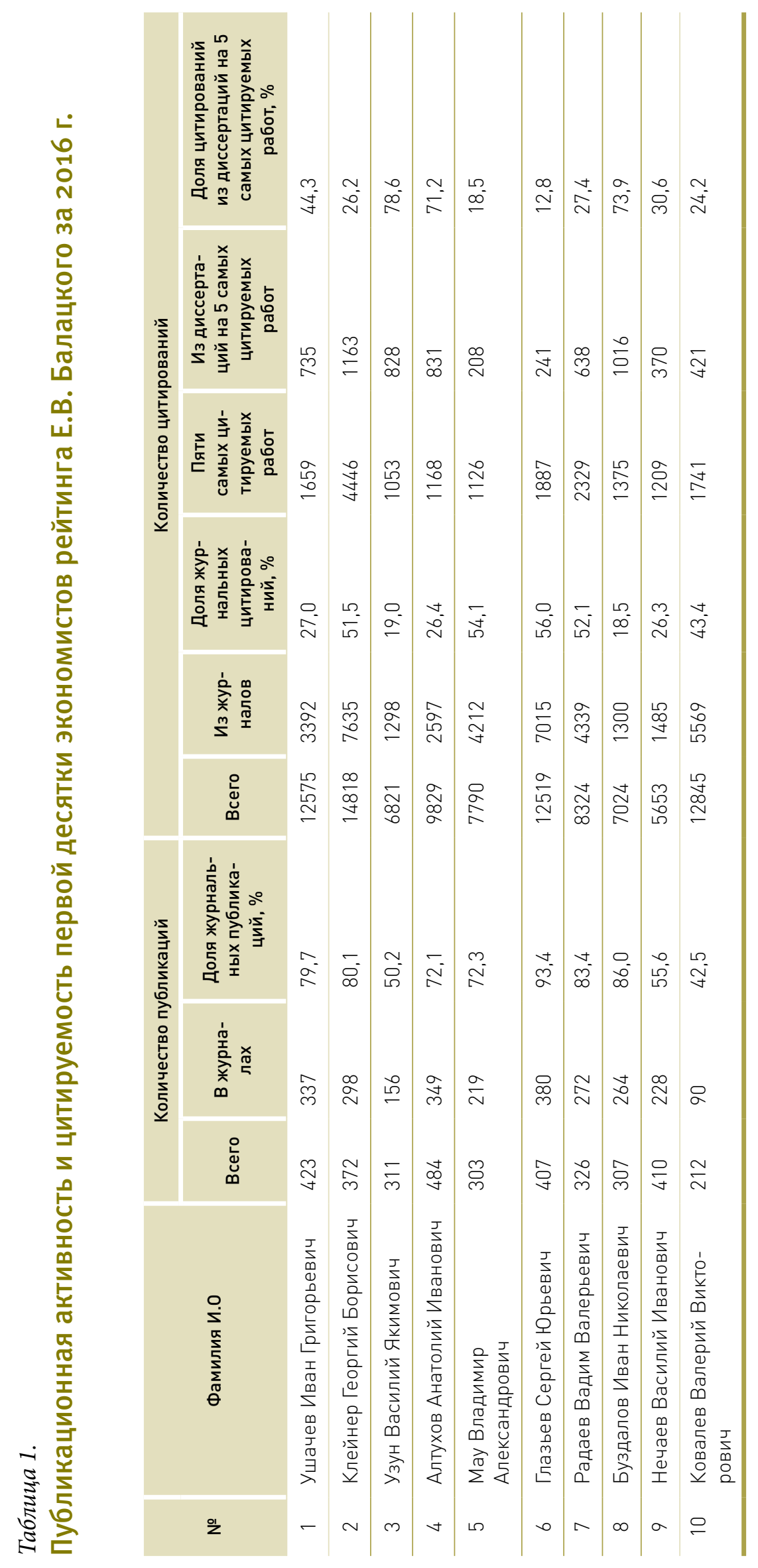




\section{Таблица 2.}

Пять наиболее цитируемых публикаций Узун В.Я. и ссылки на них из диссертаций и авторефератов диссертаций

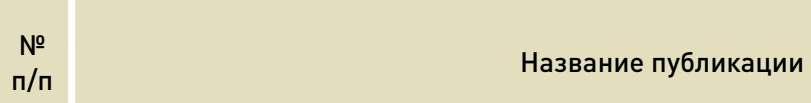

Аграрные отношения: теория, историческая практика, перспективы развития

1 Буздалов И.Н., Крылатых Э.Н., Никонов А.А., Боев В.Р., Киселев С.В., Петриков А.В., Пошкус Б.И., Серков А.Ф., Серова Е.В., Узун В.Я., Шмелев Г.И. Москва, 1993.

\begin{tabular}{|c|c|c|}
\hline \multicolumn{3}{|c|}{ Количество цитирований } \\
\hline Всего & $\begin{array}{c}\text { Из диссер- } \\
\text { таций }\end{array}$ & $\begin{array}{c}\text { В процен- } \\
\text { тах, \% }\end{array}$ \\
\hline
\end{tabular}

$424 \quad 334 \quad 78,8$

\section{Концепция аграрной политики и продовольственного обеспечения Российской} Федерации

2 Андреев П.А., Боев В.Р., Богатырев А.Н., Милосердов В.В., Никонов А.А., Пошкус 206 Б.И., Романенко Г.А., Сазонов С.Н., Узун В.Я., Шутьков А.А.

Москва, 1995.

\section{Аграрная реформа в России. Концепции, опыт, перспективы}

Буздалов И.Н., Кресникова Н.И., Крылатых Э.Н., Семенова Е.В., Петриков А.В.,

3 Серова Е.В., Строкова О.Г., Узун В.Я., Шагайда Н.И., Шмелев Г.И., Янбых Р.Г. Коллективная монография / ответственный редактор - Петриков А.В. Москва, 2000. Сер. Научные труды ВИАПИ РАСХН Том. Выпуск 4

\begin{tabular}{|c|c|c|c|c|}
\hline 4 & $\begin{array}{l}\text { Эффективность крупного и малого бизнеса в сельском хозяйстве } \\
\text { Узун В. } \\
\text { Вопросы экономики. 2005. №6.С. 109-118. }\end{array}$ & 135 & 109 & 80,7 \\
\hline 5 & $\begin{array}{l}\text { Крупный и малый бизнес в сельском хозяйстве России: адаптация к рынку } \\
\text { и эффективность } \\
\text { Узун В.Я. } \\
\text { Всероссийский институт аграрных проблем и информатики им. А.А. Никонова. } \\
\text { Москва, 2004. Сер. Научные труды Всероссийского института аграрных проблем } \\
\text { и информатики Том Выпуск } 11\end{array}$ & 134 & 71 & 53,0 \\
\hline & Всего & 1053 & 828 & 78,6 \\
\hline
\end{tabular}

\section{Таблица 3.}

Пять наиболее цитируемых публикаций Буздалова И. Н. и ссылки на них из диссертаций и авторефератов диссертаций

\begin{tabular}{|c|c|c|c|c|}
\hline \multirow{2}{*}{$\begin{array}{l}\text { № } \\
\text { п/п }\end{array}$} & \multirow[b]{2}{*}{ Название публикации } & \multicolumn{3}{|c|}{ Количество цитирований } \\
\hline & & Всего & $\begin{array}{l}\text { Из дис- } \\
\text { сертаций }\end{array}$ & $\begin{array}{c}\text { В про- } \\
\text { центах, \% }\end{array}$ \\
\hline 1 & $\begin{array}{l}\text { Аграрные отношения: теория, историческая практика, перспективы развития } \\
\text { Буздалов И.Н., Крылатых Э.Н., Никонов А.А., Боев В.Р., Киселев С.В., Петриков } \\
\text { А.В., Пошкус Б.И., Серков А.Ф., Серова Е.В., Узун В.Я., Шмелев Г.И. } \\
\text { Москва, } 1993 .\end{array}$ & 424 & 334 & 78,8 \\
\hline 2 & $\begin{array}{l}\text { Рыночные отношения в АПК России: Современное состояние и перспективы } \\
\text { Шутьков А.А., Назаренко В.И., Ушачев И.Г., Черняков Б.А., Крылатых Э.Н., } \\
\text { Беспахотный Г.В., Макин Г.И., Буздалов И.Н., Серков А.Ф., Лысенкова Т.М., } \\
\text { Жоголева Е.Е. } \\
\text { Москва, } 1997 .\end{array}$ & 278 & 244 & 87,8 \\
\hline 3 & $\begin{array}{l}\text { Концепция аграрной политики России в 1997-2000 годах } \\
\text { Алексеев А.И., Амосов А.И., Беляева З.С., Буздалов И.Н., Волконский В.А., } \\
\text { Зубаревич Н.В., Кирюшин В.И., Кознова И.Е., Никольский С.А., Филиппов В.Р., } \\
\text { Филиппова Е.И., Шмелев Г.И. } \\
\text { Под редакцией Е.С. Строева. Москва, } 1997 .\end{array}$ & 236 & 207 & 87,7 \\
\hline
\end{tabular}


Таблица 3. (Продолжение)

Пять наиболее цитируемых публикаций Буздалова И. Н. и ссылки на них из диссертаций и авторефератов диссертаций

\begin{tabular}{|c|c|c|c|c|}
\hline \multirow{2}{*}{$\begin{array}{l}\text { № } \\
\text { п/п }\end{array}$} & \multirow[b]{2}{*}{ Название публикации } & \multicolumn{3}{|c|}{ Количество цитирований } \\
\hline & & Всего & $\begin{array}{l}\text { Из дис- } \\
\text { сертаций }\end{array}$ & $\begin{array}{c}\text { В про- } \\
\text { центах, \% }\end{array}$ \\
\hline 4 & $\begin{array}{l}\text { Земельный вопрос } \\
\text { Строев Е.С., Бабашкин В.В., Борхунов Н.А., Быстров Г.Е., Буздалов И.Н., } \\
\text { Гвидичини П., Германсдорфер У., Домников С.Д., Емельянова С.С., Ивлева Т.Н., } \\
\text { Иконицкая И.А., Кирюшин В.И., Кознова И.Е., Коробейников М.А., Кузьмина Т.А., } \\
\text { Кульман У., Леркен Г., Маркарьян С.Б., Маруев С.А., Марасти Ф. и др. } \\
\text { Е.С.Строев - ответственный редактор, С.А.Никольский - заместитель } \\
\text { ответственного редактора. Москва, 1999. }\end{array}$ & 221 & 136 & 61,5 \\
\hline 5 & $\begin{array}{l}\text { Аграрная теория: концептуальные основы, исторические тенденции, } \\
\text { современные представления } \\
\text { Буздалов И.Н. } \\
\text { Монография / Москва, } 2005 .\end{array}$ & 214 & 95 & 44,4 \\
\hline & Всего & 1373 & 1016 & 74,0 \\
\hline
\end{tabular}

вышеуказанного рейтинга, полученные за период времени с 19 по 21 февраля 2017 г.

Расчет данных в 7-й и 8-й строках таблицы 1 показан на примере третьего и восьмого автора и приведен в таблицах 2 и 3.

Как видим из этих таблиц, доля цитирований из диссертаций на 5 наиболее цитируемых статей рассматриваемых авторов очень большая.

\section{Сравнительный анализ экономических рейтингов Е.В. Балацкого за 2015 и 2016 гг.}

В Приложении 1 дано сравнение ТОР-300 рейтинга Е.В. Балацкого за 2015 год с ТОР300 этого же рейтинга за 2016 год. В Приложении 2 проделана обратная процедура. Нули в этих Приложениях соответствуют отсутствию данных.

Из Приложения 1 видим, что пересечение рейтингов Е.В. Балацкого на интервале ТОР-300 составляет 182 или (182/300)

117 ученьх-экономистов из рейтинга 2016 г. не входили в рейтинг 2015 г., что говорит о кардинальном различии обеих методологий х $100 \%=61 \% .117$ ученых-экономистов из рейтинга 2016 г. не входили в рейтинг 2015 г., что является очень большим процентом и говорит о кардинальном различии обеих методологий. При этом мы понимаем, что сравнения по разным методологиям сделаны со сдвижкой на один год. На рисунке 3 приведены наши расчеты по пирсоновской корреляции для обоих рейтингов. В поле точек учтены все данные ТОР-300 рейтинга за 2015 г. и соответствующие им пересекающиеся данные ТОР-500 рейтинга за 2016 г. На рисунке 4 показана обратная ситуация. Как видим, во втором случае теснота связи была практически в два раза лучше.

Эти расчеты также показывают плохую сходимость данных между рейтингами Е.В. Балацкого, подсчитанных по двум разным методологиям.

\section{Заключение}

работе показано, что расчет рейтингов ученых на основе стандартных показателей РИНЦ (общее количество публикаций и цитирований, индекс Хирша) без привязывания этих показателей к журнальным публикациям является ошибочным, так как в этом случае мы обнаруживаем чрезмерно большое число 

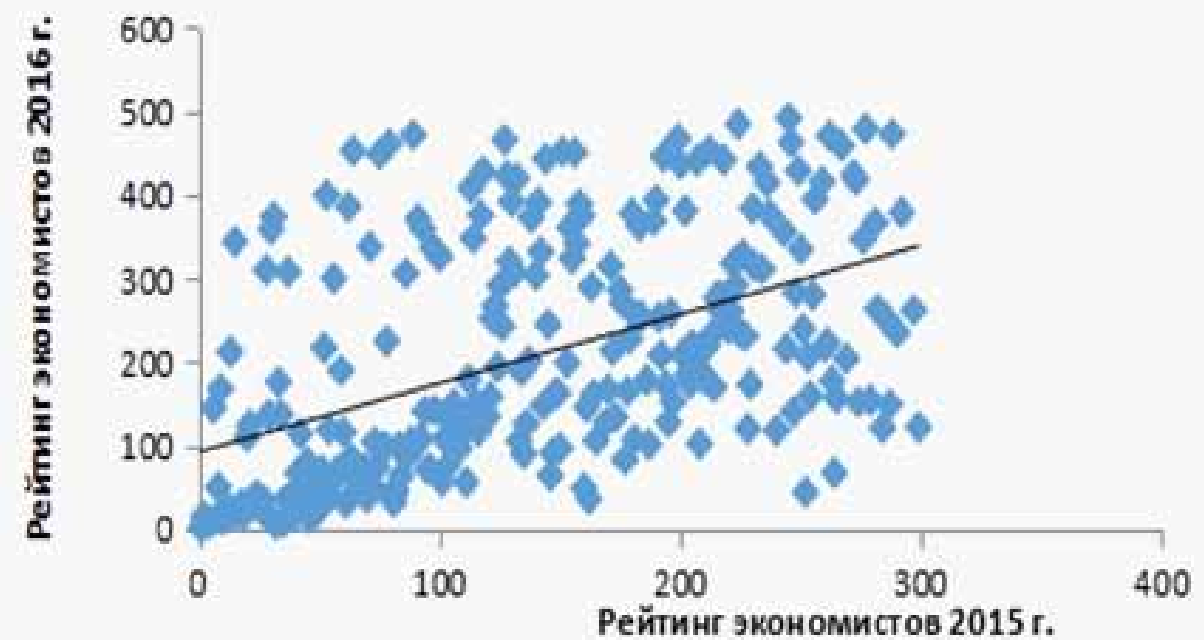

$y=0.8249 x+92.079$

$R^{2}=0.2406$

Рейтинг экономистов $2015 \mathrm{r}$.

Рисунок 3.

Взаимная корреляция рейтингов Е.В. Балацкого за разные годы, когда на оси х отложены данные ТОР-300 рейтинга Е.В. Балацкого за 2015 г.
$\mathrm{y}=0.9272 \mathrm{x}+30.769$ $\mathrm{R}^{2}=0.4387$

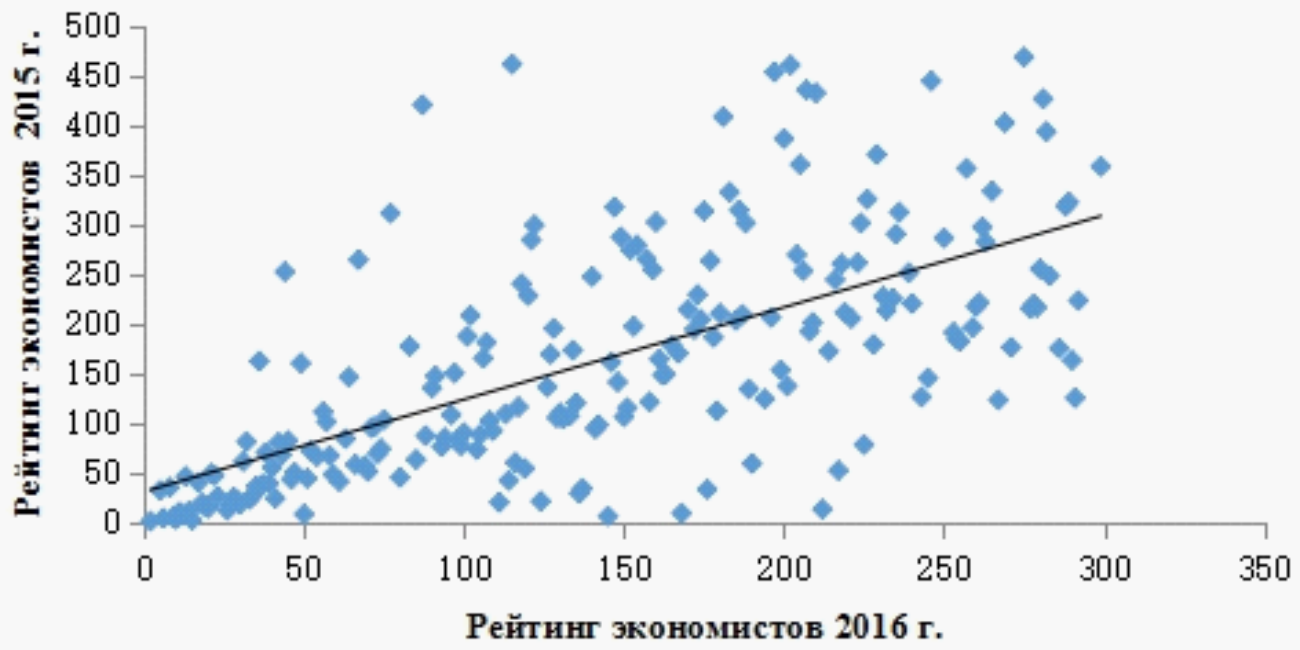

Рисунок 4.

Взаимная корреляция рейтингов Е.В. Балацкого за разные годы, когда на оси х отложены данные ТОР-300 рейтинга Е.В. Балацкого за 2016 г.

накручивания ссылок членов этого оргкомитета. Проделан сравнительный корреляционно-регрессионный анализ рейтингов российских экономистов Е.В.

цитирований учебников и монографий, идущих из диссертаций и их авторефератов. Данный вывод сделан из расчетов по рейтингу Е.В. Балацкого за 2016 г. Формализована известная преступная схема накручивания цитируемости и индекса Хирша, которая использует две различные группы журналов, в одной из которых публикуются статьи членов преступного оргкомитета конференций, а во второй журналы, используемые для Балацкого за 2015 и 2016 гг., который показал на плохую их согласованность, что говорит о значительных различиях в методологиях их расчетов.

\section{Финансирование:}

Работа поддержана в рамках Государственного задания Минобрнауки РФ на 2016 г., код проекта -516 . 


\section{ИСТОЧнИКИ:}

1. Garfield, E. Citation Analysis as a tool in journal evaluation / E.Garfield // Science. 1972. - Vol. 178. - P. 471-479.

2. Hirsch, J. E. An index to quantify an individual's scientific research output / J.E. Hirsch // Proceedings of the National Academy of Sciences. - 2005. — Vol. 102, № 46. P.16569-16572.

3. Waltman, L. The inconsistency of the h-in$\operatorname{dex} /$ L. Waltman, N.J. van Eck // Journal of the American Society for Information Science and Technology. - 2012. - Vol. 63, № 2. - P. 406-415.

4. Bornmann, L. A multilevel meta-analysis of studies reporting correlations between the $h$ index and 37 different $h$ index variants / $L$. Bornmann, R. Mutz, H.-D. Daniel // Journal of Informetrics. - 2011. - Vol. 5, № 3. P. 346-359.

5. Marchant, T. Score-based bibliometric rankings of authors / T. Marchant // Journal of the American Society for Information Science and Technology . - 2009. Vol. 60, № 6. - P. 1132-1137.

6. Moskovkin, V.M. Construction IF-Scoring Rule Within The Framework of New Generation of Metric Citations / V.M. Moskovkin, N.A. Golikov, I.F. Isaev, O. V. Serkina // Research Journal of Applied Sciences, 2014. - Vol. 9, № 12. - P. 1167-1170.

7. Московкин, В.М. Конструирование метрик цитирования нового поколения / В.М. Московкин, Н.А. Голиков, О.В. Серкина // Научно-техническая информация. Сер. 2. Информационные процессы и системы. - 2015. - № 8. - С. 30-36.

8. Арзамасцев, А.А. Использование методов математического моделирования и искусственного интеллекта для оценки деятельности научных работников / А.А. Арзамасцев, К.Г. Троич, Н.А. Зенкова, А.В. Неудахин // Вестник Тамбовского университета. Серия: Естественные и технические науки. - 2008. - Том 13, № 4. - С. 301-312.

9. Штенников, В.Н., Научные рейтинги, или санкции по-русски / В.Н. Штенников,
А.Ю. Зяблова // Биржа интеллектуальной собственности. - 2015. - Том 14 , № $10 .-$ C.20-22.

10. Кирвас, В.А. Научнометрическая оценка результатов исследований деятельности ученых и качества периодических научных изданий / В.А. Кирвас // Системи обробки інформаціi. - 2013. Вип. 8 (115). - С. 5-15.

11. Дежина, И.Г. Есть ли в России ведущие экономисты и кто они? / И.Г. Дежина, В.В. Дашкеев. Научные труды Института экономики переходного периода. - М.: ИЭПП, 2008. - 21c.

12. Балацкий, Е.В. Рейтингование участников российского рынка экономических исследований / Е.В. Балацкий, Н.А. Екимова // Journal Institutional Studies (Журнал институциональных исследований). 2015. - Т. 7. № 3. - С.102-121.

13. Рейтинг академической активности и популярности экономистов России ( http:// nonerg-econ.ru/cat/18/7/)

14. Золотой рейтинг академической активности и популярности экономистов России (2016). [Электронный ресурс] // Неэргодическая экономика. 25.02.2016. Режим доступа: http://nonerg-econ.ru/ cat $/ 9 / 57$

15. Балацкий, Е.В. Несбалансированность наукометрических РИНЦ-показателей российских экономистов / Е.В. Балацкий, М.А. Юревич // Журнал НЭА. - 2016. № 2(30). - С.176-180.

16. Шумилов, А.В. Академические рейтинги RelEc: вопросы построения и роль российских участников / А.В. Шумилов, E.B. Балацкий // Munich Personal RePEc ArchivPaper No.70956 (http://mpra.ub.unimuenchen.de/70956/)

17. Ростовцев, А.А. Дата-социология и некоторые проблемы научной аттестации / А.А. Ростовцев // Наука. Инновации. Образование. - 2015. - № 18. - С.244254. URL: http://cyberleninka.ru/article/n/ data-sotsiologiya-i-nekotorye-problemynauchnoy-attestatsii (дата обращения: 28.12.2016). 
Vladimir M. Moskovkin ${ }^{1}$, Sun Xingyuan ${ }^{1}$

${ }^{1}$ Belgorod National Research University, Russia

表汪 moskovkinabsu.edu.ru

\section{Economist Rankings: Modern State and Prospects for Future Studies}

\section{Abstract:}

'The article presents the calculation of the scientists' rankings based on standard

Indicators of Russian Science Citation Index (RSCI) without binding these indicators to the journal publication is erroneous, as in this case, it reveals an excessive number of citations of textbooks and monographs coming from the dissertations and their abstracts.

This conclusion is drawn from calculations by E.V. Balatsky rating for 2016 which formalized a known criminal scheme of wrapping of the citation and h-index, which uses two different groups of journals, one of which publishes articles of the members of the conference organizing Committee, and secondly, is the journal used for the wrapping links of the members of the organizing Committee. The article presents also a comparative correlation-regression analysis of Russian economists' rankings of E.V. Balatsky for 2015 and 2016., which showed a bad consistency, which indicates significant differences in their calculation methodologies.

Keywords: scientist rankings, economist rankings, RSCI, publication activity, citation, h-index

\section{Cite as:}

Vladimir M. Moskovkin, Sun Xingyuan. (2017). Reytingovaniye ekonomistov: sovremennoye sostoyaniye voprosa i perspektivy dal'neyshikh issledovaniy [Economist Rankings: Modern State and Prospects for Future Studies]. Nauchnaya periodika: problemy i resheniya [Scholarly Communication Review, ISSN 2218-7766], 7(1). P. 20-45, doi: 10.18334/ nppir.7.1.38336 (in Russian).

\section{Highlights:}

- titled scientists at the top of the rankings are winning through a huge number of links to their monographs and textbooks, coming mainly from theses

- the tradition of preferential citation of a certain range of award-winning scientists comes from the Soviet era

— in Soviet times, there were no "Publish or Perish" races for a number of publications and h-index, but was the desire to publish good paper in domestic or foreign academic respectable journal

- 117 scientists and economists from the rating 2016 didn't take part in the rating 2015, that shows the fundamental differences in both methodologies

- the calculation of the rankings of scientists based on standard RSCI indicators without tying these indicators to the journal publications is incorrect, as in this case, we find an unusually large number of citations of books and monographs from theses and their abstracts

\section{References}

Arzamastsev, A.A. (2008). Ispol'zovaniye metodov matematicheskogo modelirovaniya i iskusstvennogo intellekta dlya otsenki deyatel'nosti nauchnykh rabotnikov [The use of methods of mathematical modeling and artificial intelligence to assess the activities of scientists]. Vestnik Tambovskogo universiteta. Seriya: Yestestvennyye i tekhnicheskiye nauki, 13(4). 301-312. (in Russian). 
Balatskiy, Ye.V. (2015). Reytingovaniye uchastnikov rossiyskogo rynka ekonomicheskikh issledovaniy [Rating of participants of the Russian market of economic research]. Journal of Institutional Studies (Zhurnal institutsional'nykh issledovaniy), 7(3). 102121. (in Russian).

Balatskiy, Ye.V. (2016). Nesbalansirovannost' naukometricheskikh RINTS-pokazateley rossiyskikh ekonomistov [The imbalance of science-metric RSCI indicators of Russian economists]. Journal of New Economic Association, (2). 176-180. (in Russian).

Bornmann, L. (2011). A multilevel meta-analysis of studies reporting correlations between the $\mathrm{h}$ index and 37 different $\mathrm{h}$ index variants. Journal of Informetrics, 5(3). 346-359.

Dezhina, I.G. (2008). Yest' li v Rossii vedushchiye ekonomisty i kto oni? [Are there any leading economists in Russia and who are they?]. Nauchnyye trudy Instituta ekonomiki perekhodnogo perioda. Moscow, IEPP. (in Russian).

Garfield, E. (1972). Citation Analysis as a tool in journal evaluation. Science, 178. 471479.

Hirsch, J.E. (2005). An index to quantify an individual's scientific research output. Proceedings of the National Academy of Sciences, 102(46). 16569-16572.

Kirvas, V.A. (2013). Nauchnometricheskaya otsenka rezul'tatov issledovaniy deyatel'nosti uchenykh i kachestva periodicheskikh nauchnykh izdaniy [Scientific-scientific evaluation of research results of scientists and the quality of periodical scientific publications]. Sistemi obrobki informatsii, (8). 5-15. (in Russian).

Marchant, T. (2009). Score-based bibliometric rankings of authors. Journal of the American Society for Information Science and Technology, 60(6). 1132-1137.

Moskovkin, V.M. (2014). Construction IF-Scoring Rule Within the Framework of New Generation of Metric Citations. Research Journal of Applied Sciences, 9(12). 11671170.

Moskovkin, V.M. (2015). Konstruirovaniye metrik tsitirovaniya novogo poko-leniya [Construction of new generation citation metrics]. Nauchno-tekhnicheskaya informatsiya. Ser. 2. Informatsionnyye protsessy i sistemy, (8). 30-36. (in Russian).

Reyting akademicheskoy aktivnosti i populyarnosti ekonomistov Rossii [Rating of academic activity and popularity of economists in Russia]. (2015). Neergodicheskaya ekonomika. url: http://nonerg-econ.ru/cat/18/7/ (in Russian).

Rostovtsev, A.A. (2015). Data-sotsiologiya i nekotoryye problemy nauchnoy attestatsii [Data-sociology and some problems of scientific attestation]. Nauka. Innovatsii. Obrazovaniye, (18). 244-254. (in Russian).

Shtennikov, V.N. (2015). Nauchnyye reytingi, ili sanktsii po-russki [Scientific Ratings, or Sanctions in Russian]. Birzha intellektual'noy sobstvennosti, 14(10). 20-22. (in Russian).

Shumilov, A.V. (2016). Akademicheskiye reytingi RelEc: voprosy postroyeniya i rol' rossiyskikh uchastnikov [Academic ratings of RelEc: construction issues and the role of Russian participants]. Munich Personal RePEc ArchivPaper, No.70956. url: http:// mpra.ub.uni-muenchen.de/70956/ (in Russian).

Waltman, L. (2012). The inconsistency of the h-index. Journal of the American Society for Information Science and Technology, 63(2). 406-415.

Zolotoy reyting akademicheskoy aktivnosti i populyarnosti ekonomistov Rossii

[Gold rating of academic activity and popularity of Russian economists] (2016).

Neergodicheskaya ekonomika. url: http://nonerg-econ.ru/cat/9/57 (in Russian). 


\section{Приложение 1}

\begin{tabular}{|c|c|c|c|}
\hline & 2015 г. & & 2016 г. \\
\hline № & Ф.И.0. & № & Ф.И.о. \\
\hline 1 & Клейнер Георгий Борисович & 2 & Клейнер Георгий Борисович \\
\hline 2 & Гохберг Леонид Маркович & 15 & Гохберг Леонид Маркович \\
\hline 3 & Ковалев Валерий Викторович & 10 & Ковалев Валерий Викторович \\
\hline 4 & Глазьев Сергей Юрьевич & 6 & Глазьев Сергей Юрьевич \\
\hline 5 & Нечаев Василий Иванович & 9 & Нечаев Василий Иванович \\
\hline 6 & Асаул Анатолий Николаевич & 145 & Асаул Анатолий Николаевич \\
\hline 7 & Абалкин Леонид Иванович & 12 & Абалкин Леонид Иванович \\
\hline 8 & Кузьминов Ярослав Иванович & 50 & Кузьминов Ярослав Иванович \\
\hline 9 & Логинов Евгений Леонидович & 168 & Логинов Евгений Леонидович \\
\hline 10 & Татаркин Александр Иванович & 11 & Татаркин Александр Иванович \\
\hline 11 & Ендовицкий Дмитрий Александрович & 14 & Ендовицкий Дмитрий Александрович \\
\hline 12 & Шеремет Анатолий Данилович & 26 & Шеремет Анатолий Данилович \\
\hline 13 & Райзберг Борис Абрамович & 212 & Райзберг Борис Абрамович \\
\hline 14 & Попов Евгений Васильевич & 20 & Попов Евгений Васильевич \\
\hline 15 & Ряховская Антонина Николаевна & 344 & Ряховская Антонина Николаевна \\
\hline 16 & Капелюшников Ростислав Исаакович & 19 & Капелюшников Ростислав Исаакович \\
\hline 17 & Хрусталев Евгений Юрьевич & 27 & Хрусталев Евгений Юрьевич \\
\hline 18 & Полтерович Виктор Меерович & 30 & Полтерович Виктор Меерович \\
\hline 19 & Сухарев Олег Сергеевич & 18 & Сухарев Олег Сергеевич \\
\hline 20 & Кузнецова Ирина Александровна & 111 & Кузнецова Ирина Александровна \\
\hline 21 & Агеев Александр Иванович & 124 & Агеев Александр Иванович \\
\hline 22 & Балацкий Евгений Всеволодович & 29 & Балацкий Евгений Всеволодович \\
\hline 23 & Мельник Маргарита Викторовна & 33 & Мельник Маргарита Викторовна \\
\hline 24 & Лексин Владимир Николаевич & 41 & Лексин Владимир Николаевич \\
\hline 25 & Макаров Валерий Леонидович & 28 & Макаров Валерий Леонидович \\
\hline 26 & Иншаков Олег Васильевич & 23 & Иншаков Олег Васильевич \\
\hline 27 & Зубченко Лилия Александровна & 34 & Зубченко Лилия Александровна \\
\hline 28 & Суглобов Александр Евгеньевич & 310 & Суглобов Александр Евгеньевич \\
\hline 29 & Шегельман Илья Романович & 136 & Шегельман Илья Романович \\
\hline 30 & Котляров Иван Дмитриевич & 359 & Котляров Иван Дмитриевич \\
\hline 31 & Адамов Насрулла Абдурахманович & 374 & Адамов Насрулла Абдурахманович \\
\hline 32 & Мау Владимир Александрович & 5 & Мау Владимир Александрович \\
\hline 33 & Стародубцева Елена Борисовна & 176 & Стародубцева Елена Борисовна \\
\hline 34 & Кибанов Ардальон Яковлевич & 137 & Кибанов Ардальон Яковлевич* \\
\hline 35 & Буздалов Иван Николаевич & 8 & Буздалов Иван Николаевич \\
\hline 36 & Нуреев Рустем Махмутович & 35 & Нуреев Рустем Махмутович \\
\hline 37 & Цветков Валерий Анатольевич & 308 & Цветков Валерий Анатольевич \\
\hline 38 & Яковец Юрий Владимирович & 37 & Яковец Юрий Владимирович \\
\hline 39 & Яковлев Андрей Александрович & 39 & Яковлев Андрей Александрович \\
\hline
\end{tabular}




\begin{tabular}{|c|c|c|c|}
\hline & 2015 г. & & 2016 г. \\
\hline № & Ф.и.о. & № & Ф.и.о. \\
\hline 40 & Соколов Ярослав Вячеславович & 17 & Соколов Ярослав Вячеславович \\
\hline 41 & Жилина Ирина Юрьевна & 67 & Жилина Ирина Юрьевна \\
\hline 42 & Айвазян Сергей Артемьевич & 114 & Айвазян Сергей Артемьевич \\
\hline 43 & Бычкова Светлана Михайловна & 46 & Бычкова Светлана Михайловна \\
\hline 44 & Швецов Александр Николаевич & 51 & Швецов Александр Николаевич \\
\hline 45 & Безрукова Татьяна Львовна & 80 & Безрукова Татьяна Львовна \\
\hline 46 & Румянцева Елена Евгеньевна & 13 & Румянцева Елена Евгеньевна \\
\hline 47 & Павлов Константин Викторович & 22 & Павлов Константин Викторович \\
\hline 48 & Алборов Ролан Архипович & 59 & Алборов Ролан Архипович \\
\hline 49 & Радыгин Александр Дмитриевич & 21 & Радыгин Александр Дмитриевич \\
\hline 50 & Вахрушина Мария Арамовна & 47 & Вахрушина Мария Арамовна \\
\hline 51 & Кузык Борис Николаевич & 70 & Кузык Борис Николаевич \\
\hline 52 & Сулакшин Степан Степанович & 217 & Сулакшин Степан Степанович \\
\hline 53 & Мингалева Жанна Аркадьевна & 400 & Мингалева Жанна Аркадьевна \\
\hline 54 & Басовский Леонид Ефимович & 119 & Басовский Леонид Ефимович \\
\hline 55 & Шаститко Андрей Евгеньевич & 40 & Шаститко Андрей Евгеньевич \\
\hline 56 & Одегов Юрий Геннадьевич & 300 & Одегов Юрий Геннадьевич \\
\hline 57 & Мохначев Сергей Анатольевич & 69 & Мохначев Сергей Анатольевич \\
\hline 58 & Колин Константин Константинович & 66 & Колин Константин Константинович \\
\hline 59 & Елисеева Ирина Ильинична & 190 & Елисеева Ирина Ильинична \\
\hline 60 & Лаврушин Олег Иванович & 116 & Лаврушин Олег Иванович \\
\hline 61 & Зельднер Алексей Григорьевич & 31 & Зельднер Алексей Григорьевич \\
\hline 62 & Хоружий Людмила Ивановна & 386 & Хоружий Людмила Ивановна \\
\hline 63 & Бобков Вячеслав Николаевич & 85 & Бобков Вячеслав Николаевич \\
\hline 64 & Шаталова Татьяна Николаевна & 453 & Шаталова Татьяна Николаевна \\
\hline 65 & Марцинкевич Виктор Иосифович & 0 & Марцинкевич Виктор Иосифович \\
\hline 66 & Тамбовцев Виталий Леонидович & 54 & Тамбовцев Виталий Леонидович \\
\hline 67 & Керимов Вагиф Эльдарович & 58 & Керимов Вагиф Эльдарович \\
\hline 68 & Гринберг Руслан Семенович & 43 & Гринберг Руслан Семенович \\
\hline 69 & Ясин Евгений Григорьевич & 73 & Ясин Евгений Григорьевич \\
\hline 70 & Пансков Владимир Георгиевич & 38 & Пансков Владимир Георгиевич \\
\hline 71 & Юрьев Владислав Михайлович & 338 & Юрьев Владислав Михайлович \\
\hline 72 & Вертакова Юлия Владимировна & 52 & Вертакова Юлия Владимировна \\
\hline 73 & Олейник Антон Николаевич & 104 & Олейник Антон Николаевич \\
\hline 74 & Варнавский Владимир Гаврилович & 74 & Варнавский Владимир Гаврилович \\
\hline 75 & Вукович Галина Григорьевна & 449 & Вукович Галина Григорьевна \\
\hline 76 & Лившиц Вениамин Наумович & 93 & Лившиц Вениамин Наумович \\
\hline 77 & Латов Юрий Валерьевич & 99 & Латов Юрий Валерьевич \\
\hline 78 & Львов Дмитрий Семенович & 225 & Львов Дмитрий Семенович \\
\hline 79 & Чебыкина Марина Владимировна & 461 & Чебыкина Марина Владимировна \\
\hline 80 & Мильнер Борис Захарович & 42 & Мильнер Борис Захарович \\
\hline
\end{tabular}




\begin{tabular}{|c|c|c|c|}
\hline & 2015 г. & & 2016 г. \\
\hline № & Ф.И.о. & № & Ф.и.о. \\
\hline 81 & Санду Иван Степанович & 32 & Санду Иван Степанович \\
\hline 82 & Иванова Наталья Ивановна & 45 & Иванова Наталья Ивановна \\
\hline 83 & Дежина Ирина Геннадиевна & 98 & Дежина Ирина Геннадиевна \\
\hline 84 & Сенчагов Вячеслав Константинович & 63 & Сенчагов Вячеслав Константинович \\
\hline 85 & Лермонтов Юрий Михайлович & 94 & Лермонтов Юрий Михайлович \\
\hline 86 & Нижегородцев Роберт Михайлович & 306 & Нижегородцев Роберт Михайлович \\
\hline 87 & Федотова Марина Алексеевна & 88 & Федотова Марина Алексеевна \\
\hline 88 & Ильенкова Наталья Дмитриевна & 105 & Ильенкова Наталья Дмитриевна \\
\hline 89 & Сорочайкин Андрей Никонович & 472 & Сорочайкин Андрей Никонович \\
\hline 90 & Авдашева Светлана Борисовна & 100 & Авдашева Светлана Борисовна \\
\hline 91 & Герасимов Алексей Николаевич & 371 & Герасимов Алексей Николаевич \\
\hline 92 & Аганбегян Абел Гезевич & 109 & Аганбегян Абел Гезевич \\
\hline 93 & Шувалова Ольга Романовна & 360 & Шувалова Ольга Романовна \\
\hline 94 & Виханский Олег Самуилович & 141 & Виханский Олег Самуилович \\
\hline 95 & Минакир Павел Александрович & 71 & Минакир Павел Александрович \\
\hline 96 & Эпштейн Давид Беркович & 72 & Эпштейн Давид Беркович \\
\hline 97 & Трещевский Юрий Игоревич & 337 & Трещевский Юрий Игоревич \\
\hline 98 & Пятов Михаил Львович & 142 & Пятов Михаил Львович \\
\hline 99 & Дли Максим Иосифович & 330 & Дли Максим Иосифович \\
\hline 100 & Шевченко Игорь Викторович & 326 & Шевченко Игорь Викторович \\
\hline 101 & Бузгалин Александр Владимирович & 57 & Бузгалин Александр Владимирович \\
\hline 102 & Крюков Валерий Анатольевич & 108 & Крюков Валерий Анатольевич \\
\hline 103 & Плотников Владимир Александрович & 75 & Плотников Владимир Александрович \\
\hline 104 & Новоселов Александр Сергеевич & 131 & Новоселов Александр Сергеевич \\
\hline 105 & Шагайда Наталья Ивановна & 129 & Шагайда Наталья Ивановна \\
\hline 106 & Бекетов Николай Викторович & 150 & Бекетов Николай Викторович \\
\hline 107 & Горемыкин Виктор Андреевич & 133 & Горемыкин Виктор Андреевич \\
\hline 108 & Метелев Сергей Ефимович & 96 & Метелев Сергей Ефимович \\
\hline 109 & Трубилин Александр Иванович & 113 & Трубилин Александр Иванович \\
\hline 110 & Голубев Алексей Валерианович & 130 & Голубев Алексей Валерианович \\
\hline 111 & Гайдар Егор Тимурович* & 56 & Гайдар Егор Тимурович* \\
\hline 112 & Блинов Андрей Олегович & 179 & Блинов Андрей Олегович \\
\hline 113 & Кутер Михаил Исаакович & 408 & Кутер Михаил Исаакович \\
\hline 114 & Тинякова Виктория Ивановна & 348 & Тинякова Виктория Ивановна \\
\hline 115 & Зубаревич Наталья Васильевна & 151 & Зубаревич Наталья Васильевна \\
\hline 116 & Кулешов Валерий Владимирович & 117 & Кулешов Валерий Владимирович \\
\hline 117 & Костюкова Елена Ивановна & 376 & Костюкова Елена Ивановна \\
\hline 118 & Сибирская Елена Викторовна & 428 & Сибирская Елена Викторовна \\
\hline 119 & Гуриев Сергей Маратович & 0 & Гуриев Сергей Маратович \\
\hline 120 & Кирдина Светлана Георгиевна & 135 & Кирдина Светлана Георгиевна \\
\hline 121 & Бухвальд Евгений Моисеевич & 158 & Бухвальд Евгений Моисеевич \\
\hline
\end{tabular}




\begin{tabular}{|c|c|c|c|}
\hline & 2015 г. & & 2016 г. \\
\hline № & Ф.и.о. & № & Ф.И.0. \\
\hline 122 & Попова Людмила Владимировна & 252 & Попова Людмила Владимировна \\
\hline 123 & Скляров Игорь Юрьевич & 267 & Скляров Игорь Юрьевич \\
\hline 124 & Голиченко Олег Георгиевич & 194 & Голиченко Олег Георгиевич \\
\hline 125 & Громов Евгений Иванович & 291 & Громов Евгений Иванович \\
\hline 126 & Козенкова Татьяна Андреевна & 243 & Козенкова Татьяна Андреевна \\
\hline 127 & Дорошенко Юрий Анатольевич & 466 & Дорошенко Юрий Анатольевич \\
\hline 128 & Воронов Александр Александрович & 423 & Воронов Александр Александрович \\
\hline 129 & Шабунова Александра Анатольевна & 320 & Шабунова Александра Анатольевна \\
\hline 130 & Герасимов Борис Иванович & 392 & Герасимов Борис Иванович \\
\hline 131 & Ильин Владимир Александрович & 307 & Ильин Владимир Александрович \\
\hline 132 & Ягудин Семен Юрьевич & 420 & Ягудин Семен Юрьевич \\
\hline 133 & Ильенкова Светлана Дмитриевна & 105 & Ильенкова Светлана Дмитриевна \\
\hline 134 & Бендиков Михаил Абрамович & 189 & Бендиков Михаил Абрамович \\
\hline 135 & Рыбаков Феликс Федорович & 90 & Рыбаков Феликс Федорович \\
\hline 136 & Суслов Виктор Иванович & 126 & Суслов Виктор Иванович \\
\hline 137 & Цапенко Ирина Павловна & 201 & Цапенко Ирина Павловна \\
\hline 138 & Балдин Константин Васильевич & 373 & Балдин Константин Васильевич \\
\hline 139 & Яновский Валерий Витальевич & 0 & Яновский Валерий Витальевич \\
\hline 140 & Склярова Юлия Михайловна & 304 & Склярова Юлия Михайловна \\
\hline 141 & Грахов Валерий Павлович & 391 & Грахов Валерий Павлович \\
\hline 142 & Кузнецов Владимир Иванович & 332 & Кузнецов Владимир Иванович \\
\hline 143 & Маевский Владимир Иванович & 148 & Маевский Владимир Иванович \\
\hline 144 & Осипов Владимир Сергеевич & 443 & Осипов Владимир Сергеевич \\
\hline 145 & Якутин Юрий Васильевич & 245 & Якутин Юрий Васильевич \\
\hline 146 & Резник Семен Давыдович & 64 & Резник Семен Давыдович \\
\hline 147 & Нефедова Татьяна Григорьевна & 91 & Нефедова Татьяна Григорьевна \\
\hline 148 & Гимпельсон Владимир Ефимович & 162 & Гимпельсон Владимир Ефимович \\
\hline 149 & Азгальдов Гарри Гайкович & 163 & Азгальдов Гарри Гайкович \\
\hline 150 & Кузнецов Алексей Владимирович & 97 & Кузнецов Алексей Владимирович \\
\hline 151 & Роздольская Ирина Владимировна & 452 & Роздольская Ирина Владимировна \\
\hline 152 & Овчинникова Наталья Викторовна & 0 & Овчинникова Наталья Викторовна \\
\hline 153 & Кудрин Алексей Леонидович & 199 & Кудрин Алексей Леонидович \\
\hline 154 & Сагиева Галина Сибгатулловна & 361 & Сагиева Галина Сибгатулловна \\
\hline 155 & Белокрылова Ольга Спиридоновна & 324 & Белокрылова Ольга Спиридоновна \\
\hline 156 & Петраков Николай Яковлевич & 451 & Петраков Николай Яковлевич \\
\hline 157 & Аварский Наби Далгатович & 342 & Аварский Наби Далгатович \\
\hline 158 & Григорьев Леонид Маркович & 389 & Григорьев Леонид Маркович \\
\hline 159 & Веселовский Михаил Яковлевич & 375 & Веселовский Михаил Яковлевич \\
\hline 160 & Крылатых Эльмира Николаевна & 49 & Крылатых Эльмира Николаевна \\
\hline 161 & Грошев Игорь Васильевич & 146 & Грошев Игорь Васильевич \\
\hline 162 & Рисин Игорь Ефимович & 36 & Рисин Игорь Ефимович \\
\hline
\end{tabular}




\begin{tabular}{|c|c|c|c|}
\hline & 2015 г. & & 2016 г. \\
\hline № & Ф.И.0. & № & Ф.И.0. \\
\hline 163 & Васильева Марина Владимировна & 290 & Васильева Марина Владимировна \\
\hline 164 & Колганов Андрей Иванович & 161 & Колганов Андрей Иванович \\
\hline 165 & Ускова Тамара Витальевна & 106 & Ускова Тамара Витальевна \\
\hline 166 & Кудряшов Виктор Иванович & 0 & Кудряшов Виктор Иванович \\
\hline 167 & Ивантер Виктор Викторович & 0 & Ивантер Виктор Викторович \\
\hline 168 & Ковалева Наталья Васильевна & 0 & Ковалева Наталья Васильевна \\
\hline 169 & Аукуционек Сергей Павлович & 127 & Аукуционек Сергей Павлович \\
\hline 170 & Майбуров Игорь Анатольевич & 167 & Майбуров Игорь Анатольевич \\
\hline 171 & Фетисов Глеб Геннадьевич & 315 & Фетисов Глеб Геннадьевич \\
\hline 172 & Ворожейкина Татьяна Михайловна & 214 & Ворожейкина Татьяна Михайловна \\
\hline 173 & Суспицын Сергей Алексеевич & 134 & Суспицын Сергей Алексеевич \\
\hline 174 & Хачатурян Арутюн Арутюнович & 0 & Хачатурян Арутюн Арутюнович \\
\hline 175 & Садков Виктор Георгиевич & 286 & Садков Виктор Георгиевич \\
\hline 176 & Валентей Сергей Дмитриевич & 271 & Валентей Сергей Дмитриевич \\
\hline 177 & Рязанцев Сергей Васильевич & 83 & Рязанцев Сергей Васильевич \\
\hline 178 & Кузнецова Ольга Владимировна & 165 & Кузнецова Ольга Владимировна \\
\hline 179 & Бородин Александр Иванович & 228 & Бородин Александр Иванович \\
\hline 180 & Авраамова Елена Михайловна & 378 & Авраамова Елена Михайловна \\
\hline 181 & Дынкин Александр Александрович & 107 & Дынкин Александр Александрович \\
\hline 182 & Гуртов Валерий Алексеевич & 255 & Гуртов Валерий Алексеевич \\
\hline 183 & Бережной Владимир Иванович & 363 & Бережной Владимир Иванович \\
\hline 184 & Шабаева Валентина Ивановна & 254 & Шабаева Валентина Ивановна \\
\hline 185 & Рубин Юрий Борисович & 0 & Рубин Юрий Борисович \\
\hline 186 & Гранберг Александр Григорьевич & 178 & Гранберг Александр Григорьевич \\
\hline 187 & Бакланов Петр Яковлевич & 101 & Бакланов Петр Яковлевич \\
\hline 188 & Сонин Константин Исаакович & 0 & Сонин Константин Исаакович \\
\hline 189 & Багиев Георгий Леонидови & 369 & Багиев Георгий Леонидови \\
\hline 190 & Михайлушкин Павел Валерьевич & 394 & Михайлушкин Павел Валерьевич \\
\hline 191 & Якимович Борис Анатольевич & 253 & Якимович Борис Анатольевич \\
\hline 192 & Винслав Юрий Болеславович & 208 & Винслав Юрий Болеславович \\
\hline 193 & Пашкус Вадим Юрьевич & 446 & Пашкус Вадим Юрьевич \\
\hline 194 & Хотинская Галина Игоревна & 172 & Хотинская Галина Игоревна \\
\hline 195 & Романова Ольга Александровна & 128 & Романова Ольга Александровна \\
\hline 196 & Кузьбожев Эдуард Николаевич & 259 & Кузьбожев Эдуард Николаевич \\
\hline 197 & Соколов Борис Иванович & 153 & Соколов Борис Иванович \\
\hline 198 & Баканов Михаил Иванович & 0 & Баканов Михаил Иванович \\
\hline 199 & Тюкавкин Николай Михайлович & 467 & Тюкавкин Николай Михайлович \\
\hline 200 & Куклин Александр Анатольевич & 437 & Куклин Александр Анатольевич \\
\hline 201 & Ханин Гирш Ицыкович & 209 & Ханин Гирш Ицыкович \\
\hline 202 & Лойко Валерий Иванович & 381 & Лойко Валерий Иванович \\
\hline 203 & Козлов Михаил Петрович & 185 & Козлов Михаил Петрович \\
\hline
\end{tabular}




\begin{tabular}{|c|c|c|c|}
\hline & 2015 г. & & 2016 г. \\
\hline № & Ф.и.о. & № & Ф.и.о. \\
\hline 204 & Ершов Михаил Владимирович & 174 & Ершов Михаил Владимирович \\
\hline 205 & Некипелов Александр Дмитриевич & 221 & Некипелов Александр Дмитриевич \\
\hline 206 & Егоршин Александр Петрович & 196 & Егоршин Александр Петрович \\
\hline 207 & Тихомирова Наталья Владимировна & 441 & Тихомирова Наталья Владимировна \\
\hline 208 & Грязнова Алла Георгиевна & 102 & Грязнова Алла Георгиевна \\
\hline 209 & Булатов Александр Сергеевич & 187 & Булатов Александр Сергеевич \\
\hline 210 & Генкин Борис Михайлович & 180 & Генкин Борис Михайлович \\
\hline 211 & Осипов Анатолий Константинович & 219 & Осипов Анатолий Константинович \\
\hline 212 & Строева (Старцева) Олеся Анатольевна & 454 & Строева (Старцева) Олеся Анатольевна \\
\hline 213 & Стукач Виктор Федорович & 232 & Стукач Виктор Федорович \\
\hline 214 & Волгин Николай Алексеевич & 170 & Волгин Николай Алексеевич \\
\hline 215 & Катькало Валерий Сергеевич & 277 & Катькало Валерий Сергеевич \\
\hline 216 & Карзаева Наталья Николаевна & 279 & Карзаева Наталья Николаевна \\
\hline 217 & Гумеров Рустам Раулевич & 260 & Гумеров Рустам Раулевич \\
\hline 218 & Барулин Сергей Владимирович & 442 & Барулин Сергей Владимирович \\
\hline 219 & Минервин Иосиф Георгиевич & 278 & Минервин Иосиф Георгиевич \\
\hline 220 & Фролов Даниил Петрович & 240 & Фролов Даниил Петрович \\
\hline 221 & Либман Александр Михайлович & 261 & Либман Александр Михайлович \\
\hline 222 & Фадейкина Наталья Васильевна & 318 & Фадейкина Наталья Васильевна \\
\hline 223 & Вольчик Вячеслав Витальевич & 292 & Вольчик Вячеслав Витальевич \\
\hline 224 & Строителева Тамара Григорьевна & 485 & Строителева Тамара Григорьевна \\
\hline 225 & Селиверстов Вячеслав Евгеньевич & 234 & Селиверстов Вячеслав Евгеньевич \\
\hline 226 & Селин Владимир Степанович & 329 & Селин Владимир Степанович \\
\hline 227 & Бобылев Сергей Николаевич & 231 & Бобылев Сергей Николаевич \\
\hline 228 & Костяев Александр Иванович & 120 & Костяев Александр Иванович \\
\hline 229 & Ивасенко Анатолий Григорьевич & 173 & Ивасенко Анатолий Григорьевич \\
\hline 230 & Гулин Константин Анатольевич & 384 & Гулин Константин Анатольевич \\
\hline 231 & Орехов Сергей Александрович & 314 & Орехов Сергей Александрович \\
\hline 232 & Иванов Виктор Михайлович & 0 & Иванов Виктор Михайлович \\
\hline 233 & Хорев Александр Иванович & 434 & Хорев Александр Иванович \\
\hline 234 & Дудин Михаил Николаевич & 311 & Дудин Михаил Николаевич \\
\hline 235 & Бухонова София Мирославовна & 0 & Бухонова София Мирославовна \\
\hline 236 & Ковалев Виталий Валерьевич & 415 & Ковалев Виталий Валерьевич \\
\hline 237 & Мартынова Светлана Владимировна & 377 & Мартынова Светлана Владимировна \\
\hline 238 & Аузан Александр Александрович & 0 & Аузан Александр Александрович \\
\hline 239 & Никонова Яна Игоревна & 0 & Никонова Яна Игоревна \\
\hline 240 & Бутова Татьяна Витальевна & 118 & Бутова Татьяна Витальевна \\
\hline 241 & Алескеров Фуад Тагиевич & 0 & Алескеров Фуад Тагиевич \\
\hline 242 & Ефимова Ольга Владимировна & 0 & Ефимова Ольга Владимировна \\
\hline 243 & Минаков Владимир Федорович & 356 & Минаков Владимир Федорович \\
\hline 244 & Маркова Вера Дмитриевна & 216 & Маркова Вера Дмитриевна \\
\hline
\end{tabular}




\begin{tabular}{|c|c|c|c|}
\hline & 2015 г. & & 2016 г. \\
\hline № & Ф.И.0. & № & Ф.И.0. \\
\hline 245 & Жуков Борис Михайлович & 492 & Жуков Борис Михайлович \\
\hline 246 & Лукоянчев Степан Сергеевич & 463 & Лукоянчев Степан Сергеевич \\
\hline 247 & Гельвановский Михаил Иванович & 140 & Гельвановский Михаил Иванович \\
\hline 248 & Якобсон Лев Ильич & 283 & Якобсон Лев Ильич \\
\hline 249 & Винокуров Михаил Алексеевич & 429 & Винокуров Михаил Алексеевич \\
\hline 250 & Глухов Владимир Викторович & 335 & Глухов Владимир Викторович \\
\hline 251 & Красавина Лидия Николаевна & 239 & Красавина Лидия Николаевна \\
\hline 252 & Дятлов Сергей Алексеевич & 44 & Дятлов Сергей Алексеевич \\
\hline 253 & Френкель Александр Адольфович & 206 & Френкель Александр Адольфович \\
\hline 254 & Лясников Николай Васильевич & 159 & Лясников Николай Васильевич \\
\hline 255 & Райков Александр Николаевич & 280 & Райков Александр Николаевич \\
\hline 256 & Платонова Наталья Алексеевна & 395 & Платонова Наталья Алексеевна \\
\hline 257 & Миндели Леван Элизбарович & 0 & Миндели Леван Элизбарович \\
\hline 258 & Качалов Роман Михайлович & 0 & Качалов Роман Михайлович \\
\hline 259 & Бережная Елена Викторовна & 416 & Бережная Елена Викторовна \\
\hline 260 & Чекмарев Василий Владимирович & 218 & Чекмарев Василий Владимирович \\
\hline 261 & Боговиз Алексей Валентинович & 223 & Боговиз Алексей Валентинович \\
\hline 262 & Рагулина Юлия Вячеславовна & 471 & Рагулина Юлия Вячеславовна \\
\hline 263 & Сотникова Людмила Викторовна & 177 & Сотникова Людмила Викторовна \\
\hline 264 & Юданов Андрей Юрьевич & 67 & Юданов Андрей Юрьевич \\
\hline 265 & Сорокин Дмитрий Евгеньевич & 157 & Сорокин Дмитрий Евгеньевич \\
\hline 266 & Чая Владимир Тигранович & 0 & Чая Владимир Тигранович \\
\hline 267 & Пашкус Наталия Анатольевна & 459 & Пашкус Наталия Анатольевна \\
\hline 268 & Бандурин Александр Владимирович & 0 & Бандурин Александр Владимирович \\
\hline 269 & Ткач Александр Васильевич & 204 & Ткач Александр Васильевич \\
\hline 270 & Хованов Николай Васильевич & 0 & Хованов Николай Васильевич \\
\hline 271 & Серегин Сергей Николаевич & 0 & Серегин Сергей Николаевич \\
\hline 272 & Бархатов Виктор Иванович & 424 & Бархатов Виктор Иванович \\
\hline 273 & Рыжикова Зинаида Александровна & 418 & Рыжикова Зинаида Александровна \\
\hline 274 & Бочаров Владимир Владимирович & 152 & Бочаров Владимир Владимирович \\
\hline 275 & Глазырина Ирина Петровна & 0 & Глазырина Ирина Петровна \\
\hline 276 & Рогачев Алексей Фруминович & 347 & Рогачев Алексей Фруминович \\
\hline 277 & Бабкин Александр Васильевич & 479 & Бабкин Александр Васильевич \\
\hline 278 & Хашева Зарема Муратовна & 0 & Хашева Зарема Муратовна \\
\hline 279 & Иванов Виктор Владимирович & 154 & Иванов Виктор Владимирович \\
\hline 280 & Волкова Ольга Николаевна & 0 & Волкова Ольга Николаевна \\
\hline 281 & Гурнович Татьяна Генриховна & 367 & Гурнович Татьяна Генриховна \\
\hline 282 & Гетьман Виктор Григорьевич & 263 & Гетьман Виктор Григорьевич \\
\hline 283 & Гурков Игорь Борисович & 0 & Гурков Игорь Борисович \\
\hline 284 & Эскиндаров Мухадин Абдурахманович & 121 & Эскиндаров Мухадин Абдурахманович \\
\hline 285 & Ягольницер Мирон Аркадьевич & 0 & Ягольницер Мирон Аркадьевич \\
\hline
\end{tabular}




\begin{tabular}{clcc}
\hline & \multicolumn{1}{c}{2015 г. } & & 2016 г. \\
\hline № & \multicolumn{1}{c}{ Ф.0. } & №. & \\
\hline 286 & Бондаренко Людмила Васильевна & 250 & Бондаренко Людмила Васильевна \\
\hline 287 & Шишков Юрий Витальевич & 149 & Шишков Юрий Витальевич \\
\hline 288 & Митрофанова Инна Васильевна & 473 & Митрофанова Инна Васильевна \\
\hline 289 & Бельских Игорь Евгеньевич & 0 & Бельских Игорь Евгеньевич \\
\hline 290 & Окрепилов Владимир Валентинович & 235 & Окрепилов Владимир Валентинович \\
\hline 291 & Цыганов Сергей Алексеевич & 0 & Цыганов Сергей Алексеевич \\
\hline 292 & Петров Юрий Александрович & 379 & Петров Юрий Александрович \\
\hline 293 & Камалян Артак Каджикович & 0 & Камалян Артак Каджикович \\
\hline 294 & Юдкевич Мария Марковна & 0 & Юдкевич Мария Марковна \\
\hline 295 & Бухалков Михаил Ильич & 0 & Бухалков Михаил Ильич \\
\hline 296 & Демина Наталья Владимировна & 0 & Демина Наталья Владимировна \\
\hline 297 & Дадашев Алихан Заграбович & 262 & Дадашев Алихан Заграбович \\
\hline 298 & Башмачникова Елена Валентиновна & 0 & Башмачникова Елена Валентиновна \\
\hline 299 & Рубинштейн Александр Яковлевич & 122 & Рубинштейн Александр Яковлевич \\
\hline 300 & Дробышевский Сергей Михайлович & 336 & Дробышевский Сергей Михайлович \\
\hline
\end{tabular}

\section{Приложение 2}

\begin{tabular}{|c|c|c|c|}
\hline & 2016 г. & & 2015 г. \\
\hline № & Ф.и.о. & № & Ф.и.о. \\
\hline 1 & Ушачев Иван Григорьевич & 0 & Ушачев Иван Григорьевич \\
\hline 2 & Клейнер Георгий Борисович & 1 & Клейнер Георгий Борисович \\
\hline 3 & Узун Василий Якимович & 0 & Узун Василий Якимович \\
\hline 4 & Алтухов Анатолий Иванович & 0 & Алтухов Анатолий Иванович \\
\hline 5 & Мау Владимир Александрович & 32 & Мау Владимир Александрович \\
\hline 6 & Глазьев Сергей Юрьевич & 4 & Глазьев Сергей Юрьевич \\
\hline 7 & Радаев Вадим Валерьевич & 0 & Радаев Вадим Валерьевич \\
\hline 8 & Буздалов Иван Николаевич & 35 & Буздалов Иван Николаевич \\
\hline 9 & Нечаев Василий Иванович & 5 & Нечаев Василий Иванович \\
\hline 10 & Ковалев Валерий Викторович & 3 & Ковалев Валерий Викторович \\
\hline 11 & Татаркин Александр Иванович & 10 & Татаркин Александр Иванович \\
\hline 12 & Абалкин Леонид Иванович & 7 & Абалкин Леонид Иванович \\
\hline 13 & Румянцева (Жоголева) Елена Евгеньевна & 46 & Румянцева (Жоголева) Елена Евгеньевна \\
\hline 14 & Ендовицкий Дмитрий Александрович & 11 & Ендовицкий Дмитрий Александрович \\
\hline 15 & Гохберг Леонид Маркович & 2 & Гохберг Леонид Маркович \\
\hline 16 & Петриков Александр Васильевич & 0 & Петриков Александр Васильевич \\
\hline 17 & Соколов Ярослав Вячеславович & 40 & Соколов Ярослав Вячеславович \\
\hline 18 & Сухарев Олег Сергеевич & 19 & Сухарев Олег Сергеевич \\
\hline 19 & Капелюшников Ростислав Исаакович & 16 & Капелюшников Ростислав Исаакович \\
\hline 20 & Попов Евгений Васильевич & 14 & Попов Евгений Васильевич \\
\hline
\end{tabular}




\begin{tabular}{|c|c|c|c|}
\hline & 2016 г. & & 2015 г. \\
\hline № & Ф.и.о. & № & Ф.И.о. \\
\hline 21 & Радыгин Александр Дмитриевич & 49 & Радыгин Александр Дмитриевич \\
\hline 22 & Павлов Константин Викторович & 47 & Павлов Константин Викторович \\
\hline 23 & Иншаков Олег Васильевич & 26 & Иншаков Олег Васильевич \\
\hline 24 & Борхунов Николай Алексеевич & 0 & Борхунов Николай Алексеевич \\
\hline 25 & Орлов Александр Иванович & 0 & Орлов Александр Иванович \\
\hline 26 & Шеремет Анатолий Данилович & 12 & Шеремет Анатолий Данилович \\
\hline 27 & Хрусталев Евгений Юрьевич & 17 & Хрусталев Евгений Юрьевич \\
\hline 28 & Макаров Валерий Леонидович & 25 & Макаров Валерий Леонидович \\
\hline 29 & Балацкий Евгений Всеволодович & 22 & Балацкий Евгений Всеволодович \\
\hline 30 & Полтерович Виктор Меерович & 18 & Полтерович Виктор Меерович \\
\hline 31 & Зельднер Алексей Григорьевич & 61 & Зельднер Алексей Григорьевич \\
\hline 32 & Санду Иван Степанович & 81 & Санду Иван Степанович \\
\hline 33 & Мельник Маргарита Викторовна & 23 & Мельник Маргарита Викторовна \\
\hline 34 & Зубченко Лилия Александровна & 27 & Зубченко Лилия Александровна \\
\hline 35 & Нуреев Рустем Махмутович & 36 & Нуреев Рустем Махмутович \\
\hline 36 & Рисин Игорь Ефимович & 162 & Рисин Игорь Ефимович \\
\hline 37 & Яковец Юрий Владимирович & 38 & Яковец Юрий Владимирович \\
\hline 38 & Пансков Владимир Георгиевич & 70 & Пансков Владимир Георгиевич \\
\hline 39 & Яковлев Андрей Александрович & 39 & Яковлев Андрей Александрович \\
\hline 40 & Шаститко Андрей Евгеньевич & 55 & Шаститко Андрей Евгеньевич \\
\hline 41 & Лексин Владимир Николаевич & 24 & Лексин Владимир Николаевич \\
\hline 42 & Мильнер Борис Захарович & 80 & Мильнер Борис Захарович \\
\hline 43 & Гринберг Руслан Семенович & 68 & Гринберг Руслан Семенович \\
\hline 44 & Дятлов Сергей Алексеевич & 252 & Дятлов Сергей Алексеевич \\
\hline 45 & Иванова Наталья Ивановна & 82 & Иванова Наталья Ивановна \\
\hline 46 & Бычкова Светлана Михайловна & 43 & Бычкова Светлана Михайловна \\
\hline 47 & Вахрушина Мария Арамовна & 50 & Вахрушина Мария Арамовна \\
\hline 48 & Коржубаев Андрей Геннадьевич & 0 & Коржубаев Андрей Геннадьевич \\
\hline 49 & Крылатых Эльмира Николаевна & 160 & Крылатых Эльмира Николаевна \\
\hline 50 & Кузьминов Ярослав Иванович & 8 & Кузьминов Ярослав Иванович \\
\hline 51 & Швецов Александр Николаевич & 44 & Швецов Александр Николаевич \\
\hline 52 & Вертакова Юлия Владимировна & 72 & Вертакова Юлия Владимировна \\
\hline 53 & Баутин Владимир Моисеевич & 0 & Баутин Владимир Моисеевич \\
\hline 54 & Тамбовцев Виталий Леонидович & 66 & Тамбовцев Виталий Леонидович \\
\hline 55 & Янбых Рената Геннадьевна & 0 & Янбых Рената Геннадьевна \\
\hline 56 & Гайдар Егор Тимурович & 111 & Гайдар Егор Тимурович \\
\hline 57 & Бузгалин Александр Владимирович & 101 & Бузгалин Александр Владимирович \\
\hline 58 & Керимов Вагиф Эльдарович & 67 & Керимов Вагиф Эльдарович \\
\hline 59 & Алборов Ролан Архипович & 48 & Алборов Ролан Архипович \\
\hline 60 & Эдер Леонтий Викторович & 0 & Эдер Леонтий Викторович \\
\hline 61 & Жилина Ирина Юрьевна & 41 & Жилина Ирина Юрьевна \\
\hline
\end{tabular}




\begin{tabular}{|c|c|c|c|}
\hline & 2016 г. & & 2015 г. \\
\hline № & Ф.и.о. & № & Ф.И.о. \\
\hline 62 & Субетто Александр Иванович & 0 & Субетто Александр Иванович \\
\hline 63 & Сенчагов Вячеслав Константинович & 84 & Сенчагов Вячеслав Константинович \\
\hline 64 & Резник Семен Давыдович & 146 & Резник Семен Давыдович \\
\hline 65 & Шутьков Анатолий Антонович & 0 & Шутьков Анатолий Антонович \\
\hline 66 & Колин Константин Константинович & 58 & Колин Константин Константинович \\
\hline 67 & Юданов Андрей Юрьевич & 264 & Юданов Андрей Юрьевич \\
\hline 68 & Родионова Ольга Анатольевна & 0 & Родионова Ольга Анатольевна \\
\hline 69 & Мохначев Сергей Анатольевич & 57 & Мохначев Сергей Анатольевич \\
\hline 70 & Кузык Борис Николаевич & 51 & Кузык Борис Николаевич \\
\hline 71 & Минакир Павел Александрович & 95 & Минакир Павел Александрович \\
\hline 72 & Эпштейн Давид Беркович & 96 & Эпштейн Давид Беркович \\
\hline 73 & Ясин Евгений Григорьевич & 69 & Ясин Евгений Григорьевич \\
\hline 74 & Варнавский Владимир Гаврилович & 74 & Варнавский Владимир Гаврилович \\
\hline 75 & Плотников Владимир Александрович & 103 & Плотников Владимир Александрович \\
\hline 76 & Серков Александр Федорович & 0 & Серков Александр Федорович \\
\hline 77 & Папцов Андрей Геннадьевич & 311 & Папцов Андрей Геннадьевич \\
\hline 78 & Гончаров Владимир Дмитриевич & 0 & Гончаров Владимир Дмитриевич \\
\hline 79 & Пошкус Болюс Игнович & 0 & Пошкус Болюс Игнович \\
\hline 80 & Безрукова Татьяна Львовна & 45 & Безрукова Татьяна Львовна \\
\hline 81 & Филин Сергей Александрович & 0 & Филин Сергей Александрович \\
\hline 82 & Серова Евгения Викторовна & 0 & Серова Евгения Викторовна \\
\hline 83 & Рязанцев Сергей Васильевич & 177 & Рязанцев Сергей Васильевич \\
\hline 84 & Римашевская Наталья Михайловна & 0 & Римашевская Наталья Михайловна \\
\hline 85 & Бобков Вячеслав Николаевич & 63 & Бобков Вячеслав Николаевич \\
\hline 86 & Барсукова (Мисюк) Светлана Юрьевна & 0 & Барсукова (Мисюк) Светлана Юрьевна \\
\hline 87 & Черняев Анатолий Алексеевич & 420 & Черняев Анатолий Алексеевич \\
\hline 88 & Федотова Марина Алексеевна & 87 & Федотова Марина Алексеевна \\
\hline 89 & Заславская Татьяна Ивановна & 0 & Заславская Татьяна Ивановна \\
\hline 90 & Рыбаков Феликс Федорович & 135 & Рыбаков Феликс Федорович \\
\hline 91 & Нефедова Татьяна Григорьевна & 147 & Нефедова Татьяна Григорьевна \\
\hline 92 & Кундиус (Сосновских) Валентина Александровна & 0 & Кундиус (Сосновских) Валентина Александровна \\
\hline 93 & Лившиц Вениамин Наумович & 76 & Лившиц Вениамин Наумович \\
\hline 94 & Лермонтов Юрий Михайлович & 85 & Лермонтов Юрий Михайлович \\
\hline 95 & Мешалкин Валерий Павлович & 0 & Мешалкин Валерий Павлович \\
\hline 96 & Метелев Сергей Ефимович & 108 & Метелев Сергей Ефимович \\
\hline 97 & Кузнецов Алексей Владимирович & 150 & Кузнецов Алексей Владимирович \\
\hline 98 & Дежина Ирина Геннадиевна & 83 & Дежина Ирина Геннадиевна \\
\hline 99 & Латов Юрий Валерьевич & 77 & Латов Юрий Валерьевич \\
\hline 100 & Авдашева Светлана Борисовна & 90 & Авдашева Светлана Борисовна \\
\hline 101 & Бакланов Петр Яковлевич & 187 & Бакланов Петр Яковлевич \\
\hline 102 & Грязнова Алла Георгиевна & 208 & Грязнова Алла Георгиевна \\
\hline
\end{tabular}




\begin{tabular}{|c|c|c|c|}
\hline & 2016 г. & & 2015 г. \\
\hline № & Ф.И.0. & № & Ф.И.0. \\
\hline 103 & Герасимов Борис Никифорович & 0 & Герасимов Борис Никифорович \\
\hline 104 & Олейник Антон Николаевич & 73 & Олейник Антон Николаевич \\
\hline 105 & Ильенкова Наталья Дмитриевна & 88 & Ильенкова Наталья Дмитриевна \\
\hline 106 & Ускова Тамара Витальевна & 165 & Ускова Тамара Витальевна \\
\hline 107 & Дынкин Александр Александрович & 181 & Дынкин Александр Александрович \\
\hline 108 & Крюков Валерий Анатольевич & 102 & Крюков Валерий Анатольевич \\
\hline 109 & Аганбегян Абел Гезевич & 92 & Аганбегян Абел Гезевич \\
\hline 110 & Эриашвили Нодари Дарчоевич & 0 & Эриашвили Нодари Дарчоевич \\
\hline 111 & Кузнецова Ирина Александровна & 20 & Кузнецова Ирина Александровна \\
\hline 112 & Фасхиев Хакимзян Амирович & 0 & Фасхиев Хакимзян Амирович \\
\hline 113 & Трубилин Александр Иванович & 109 & Трубилин Александр Иванович \\
\hline 114 & Айвазян Сергей Артемьевич & 42 & Айвазян Сергей Артемьевич \\
\hline 115 & Алиев Басир Хабибович & 461 & Алиев Басир Хабибович \\
\hline 116 & Лаврушин Олег Иванович & 60 & Лаврушин Олег Иванович \\
\hline 117 & Кулешов Валерий Владимирович & 116 & Кулешов Валерий Владимирович \\
\hline 118 & Бутова Татьяна Витальевна & 240 & Бутова Татьяна Витальевна \\
\hline 119 & Басовский Леонид Ефимович & 54 & Басовский Леонид Ефимович \\
\hline 120 & Костяев Александр Иванович & 228 & Костяев Александр Иванович \\
\hline 121 & Эскиндаров Мухадин Абдурахманович & 284 & Эскиндаров Мухадин Абдурахманович \\
\hline 122 & Рубинштейн Александр Яковлевич & 299 & Рубинштейн Александр Яковлевич \\
\hline 123 & Миркин Яков Моисеевич & 0 & Миркин Яков Моисеевич \\
\hline 124 & Агеев Александр Иванович & 21 & Агеев Александр Иванович \\
\hline 125 & Архипова Надежда Ивановна & 0 & Архипова Надежда Ивановна \\
\hline 126 & Суслов Виктор Иванович & 136 & Суслов Виктор Иванович \\
\hline 127 & Аукуционек Сергей Павлович & 169 & Аукуционек Сергей Павлович \\
\hline 128 & Романова Ольга Александровна & 195 & Романова Ольга Александровна \\
\hline 129 & Шагайда Наталья Ивановна & 105 & Шагайда Наталья Ивановна \\
\hline 130 & Голубев Алексей Валерианович & 110 & Голубев Алексей Валерианович \\
\hline 131 & Новоселов Александр Сергеевич & 104 & Новоселов Александр Сергеевич \\
\hline 132 & Загайтов Исаак Бениаминович & 0 & Загайтов Исаак Бениаминович \\
\hline 133 & Горемыкин Виктор Андреевич & 107 & Горемыкин Виктор Андреевич \\
\hline 134 & Суспицын Сергей Алексеевич & 173 & Суспицын Сергей Алексеевич \\
\hline 135 & Кирдина (Крапчан) Светлана Георгиевна & 120 & Кирдина (Крапчан) Светлана Георгиевна \\
\hline 136 & Шегельман Илья Романович & 29 & Шегельман Илья Романович \\
\hline 137 & Кибанов Ардальон Яковлевич & 34 & Кибанов Ардальон Яковлевич \\
\hline 138 & Андрианов Владимир Дмитриевич & 0 & Андрианов Владимир Дмитриевич \\
\hline 139 & Делягин Михаил Геннадьевич & 0 & Делягин Михаил Геннадьевич \\
\hline 140 & Гельвановский Михаил Иванович & 247 & Гельвановский Михаил Иванович \\
\hline 141 & Виханский Олег Самуилович & 94 & Виханский Олег Самуилович \\
\hline 142 & Пятов Михаил Львович & 98 & Пятов Михаил Львович \\
\hline 143 & Аникин Владимир Иванович & 0 & Аникин Владимир Иванович \\
\hline
\end{tabular}




\begin{tabular}{|c|c|c|c|}
\hline & 2016 г. & & 2015 г. \\
\hline № & Ф.И.0. & № & Ф.и.о. \\
\hline 144 & Клячко Татьяна Львовна & 0 & Клячко Татьяна Львовна \\
\hline 145 & Асаул Анатолий Николаевич & 6 & Асаул Анатолий Николаевич \\
\hline 146 & Грошев Игорь Васильевич & 161 & Грошев Игорь Васильевич \\
\hline 147 & Ветитнев Александр Михайлович & 317 & Ветитнев Александр Михайлович \\
\hline 148 & Маевский Владимир Иванович & 141 & Маевский Владимир Иванович \\
\hline 149 & Шишков Юрий Витальевич & 287 & Шишков Юрий Витальевич \\
\hline 150 & Бекетов Николай Викторович & 106 & Бекетов Николай Викторович \\
\hline 151 & Зубаревич Наталья Васильевна & 115 & Зубаревич Наталья Васильевна \\
\hline 152 & Бочаров Владимир Владимирович & 274 & Бочаров Владимир Владимирович \\
\hline 153 & Соколов Борис Иванович & 197 & Соколов Борис Иванович \\
\hline 154 & Иванов Виктор Владимирович & 279 & Иванов Виктор Владимирович \\
\hline 155 & Порфирьев Борис Николаевич & 0 & Порфирьев Борис Николаевич \\
\hline 156 & Никонова (Лебедева) Яна Игоревна & 0 & Никонова (Лебедева) Яна Игоревна \\
\hline 157 & Сорокин Дмитрий Евгеньевич & 265 & Сорокин Дмитрий Евгеньевич \\
\hline 158 & Бухвальд Евгений Моисеевич & 121 & Бухвальд Евгений Моисеевич \\
\hline 159 & Лясников Николай Васильевич & 254 & Лясников Николай Васильевич \\
\hline 160 & Кизим Анатолий Александрович & 302 & Кизим Анатолий Александрович \\
\hline 161 & Колганов Андрей Иванович & 164 & Колганов Андрей Иванович \\
\hline 162 & Гимпельсон Владимир Ефимович & 148 & Гимпельсон Владимир Ефимович \\
\hline 163 & Азгальдов Гарри Гайкович & 149 & Азгальдов Гарри Гайкович \\
\hline 164 & Катровский Алексндр Петрович & 0 & Катровский Алексндр Петрович \\
\hline 165 & Кузнецова Ольга Владимировна & 178 & Кузнецова Ольга Владимировна \\
\hline 166 & Синельников-Мурылев Сергей Германович & 0 & Синельников-Мурылев Сергей Германович \\
\hline 167 & Майбуров Игорь Анатольевич & 170 & Майбуров Игорь Анатольевич \\
\hline 168 & Логинов Евгений Леонидович & 9 & Логинов Евгений Леонидович \\
\hline 169 & Адукова (Кузнецова) Алевтина Николаевна & 0 & Адукова (Кузнецова) Алевтина Николаевна \\
\hline 170 & Волгин Николай Алексеевич & 214 & Волгин Николай Алексеевич \\
\hline 171 & Никитин Александр Валерьевич & 0 & Никитин Александр Валерьевич \\
\hline 172 & Хотинская Галина Игоревна & 194 & Хотинская Галина Игоревна \\
\hline 173 & Ивасенко Анатолий Григорьевич & 229 & Ивасенко Анатолий Григорьевич \\
\hline 174 & Ершов Михаил Владимирович & 204 & Ершов Михаил Владимирович \\
\hline 175 & Шаховская Лариса Семеновна & 313 & Шаховская Лариса Семеновна \\
\hline 176 & Стародубцева Елена Борисовна & 33 & Стародубцева Елена Борисовна \\
\hline 177 & Сотникова Людмила Викторовна & 263 & Сотникова Людмила Викторовна \\
\hline 178 & Гранберг Александр Григорьевич & 186 & Гранберг Александр Григорьевич \\
\hline 179 & Блинов Андрей Олегович & 112 & Блинов Андрей Олегович \\
\hline 180 & Генкин Борис Михайлович & 210 & Генкин Борис Михайлович \\
\hline 181 & Андрюшин Сергей Анатольевич & 408 & Андрюшин Сергей Анатольевич \\
\hline 182 & Крыштановская Ольга Викторовна & 0 & Крыштановская Ольга Викторовна \\
\hline 183 & Симачев Юрий Вячеславович & 332 & Симачев Юрий Вячеславович \\
\hline 184 & Голосов Григорий Васильевич & 0 & Голосов Григорий Васильевич \\
\hline
\end{tabular}




\begin{tabular}{|c|c|c|c|}
\hline & 2016 г. & & 2015 г. \\
\hline № & Ф.и.о. & № & Ф.И.0. \\
\hline 185 & Козлов Михаил Петрович & 203 & Козлов Михаил Петрович \\
\hline 186 & Бариленко Владимир Иванович & 314 & Бариленко Владимир Иванович \\
\hline 187 & Булатов Александр Сергеевич & 209 & Булатов Александр Сергеевич \\
\hline 188 & Кондратьев Владимир Борисович & 301 & Кондратьев Владимир Борисович \\
\hline 189 & Бендиков Михаил Абрамович & 134 & Бендиков Михаил Абрамович \\
\hline 190 & Елисеева Ирина Ильинична & 59 & Елисеева Ирина Ильинична \\
\hline 191 & Шамшурина Нина Григорьевна & 0 & Шамшурина Нина Григорьевна \\
\hline 192 & Сиптиц Станислав Оттович & 0 & Сиптиц Станислав Оттович \\
\hline 193 & Карлик Александр Евсеевич & 0 & Карлик Александр Евсеевич \\
\hline 194 & Голиченко Олег Георгиевич & 124 & Голиченко Олег Георгиевич \\
\hline 195 & Шабанова Марина Андриановна & 0 & Шабанова Марина Андриановна \\
\hline 196 & Егоршин Александр Петрович & 206 & Егоршин Александр Петрович \\
\hline 197 & Широбоков Владимир Григорьевич & 453 & Широбоков Владимир Григорьевич \\
\hline 198 & Кузнецов Владимир Васильевич & 0 & Кузнецов Владимир Васильевич \\
\hline 199 & Кудрин Алексей Леонидович & 153 & Кудрин Алексей Леонидович \\
\hline 200 & Калугина Земфира Ивановна & 386 & Калугина Земфира Ивановна \\
\hline 201 & Цапенко Ирина Павловна & 137 & Цапенко Ирина Павловна \\
\hline 202 & Мартышенко Наталья Степановна & 460 & Мартышенко Наталья Степановна \\
\hline 203 & Трейвиш Андрей Ильич & 0 & Трейвиш Андрей Ильич \\
\hline 204 & Ткач Александр Васильевич & 269 & Ткач Александр Васильевич \\
\hline 205 & Цыганов Александр Андреевич & 360 & Цыганов Александр Андреевич \\
\hline 206 & Френкель Александр Адольфович & 253 & Френкель Александр Адольфович \\
\hline 207 & Лебедева Людмила Федоровна & 435 & Лебедева Людмила Федоровна \\
\hline 208 & Винслав Юрий Болеславович & 192 & Винслав Юрий Болеславович \\
\hline 209 & Ханин Гирш Ицыкович & 201 & Ханин Гирш Ицыкович \\
\hline 210 & Никулина Ольга Валерьевна & 432 & Никулина Ольга Валерьевна \\
\hline 211 & Шмелёв Николай Петрович & 0 & Шмелёв Николай Петрович \\
\hline 212 & Райзберг Борис Абрамович & 13 & Райзберг Борис Абрамович \\
\hline 213 & Игнатов Владимир Георгиевич & 0 & Игнатов Владимир Георгиевич \\
\hline 214 & Ворожейкина Татьяна Михайловна & 172 & Ворожейкина Татьяна Михайловна \\
\hline 215 & Банникова Наталья Владимировна & 0 & Банникова Наталья Владимировна \\
\hline 216 & Маркова Вера Дмитриевна & 244 & Маркова Вера Дмитриевна \\
\hline 217 & Сулакшин Степан Степанович & 52 & Сулакшин Степан Степанович \\
\hline 218 & Чекмарев Василий Владимирович & 260 & Чекмарев Василий Владимирович \\
\hline 219 & Осипов Анатолий Константинович & 211 & Осипов Анатолий Константинович \\
\hline 220 & Соболева Ирина Викторовна & 0 & Соболева Ирина Викторовна \\
\hline 221 & Некипелов Александр Дмитриевич & 205 & Некипелов Александр Дмитриевич \\
\hline 222 & Липски Станислав Анджеевич & 0 & Липски Станислав Анджеевич \\
\hline 223 & Боговиз Алексей Валентинович & 261 & Боговиз Алексей Валентинович \\
\hline 224 & Игонина Людмила Лазаревна & 301 & Игонина Людмила Лазаревна \\
\hline 225 & Львов Дмитрий Семенович & 78 & Львов Дмитрий Семенович \\
\hline
\end{tabular}




\begin{tabular}{|c|c|c|c|}
\hline & 2016 г. & & 2015 г. \\
\hline № & Ф.и.о. & № & Ф.И.0. \\
\hline 226 & Рязанов Виктор Тимофеевич & 325 & Рязанов Виктор Тимофеевич \\
\hline 227 & Зинченко Алексей Павлович & 0 & Зинченко Алексей Павлович \\
\hline 228 & Бородин Александр Иванович & 179 & Бородин Александр Иванович \\
\hline 229 & Цукерман Вячеслав Александрович & 370 & Цукерман Вячеслав Александрович \\
\hline 230 & Сагайдак Эрнест Иванович & 0 & Сагайдак Эрнест Иванович \\
\hline 231 & Бобылев Сергей Николаевич & 227 & Бобылев Сергей Николаевич \\
\hline 232 & Стукач Виктор Федорович & 213 & Стукач Виктор Федорович \\
\hline 233 & Огнивцев Сергей Борисович & 0 & Огнивцев Сергей Борисович \\
\hline 234 & Селиверстов Вячеслав Евгеньевич & 225 & Селиверстов Вячеслав Евгеньевич \\
\hline 235 & Окрепилов Владимир Валентинович & 290 & Окрепилов Владимир Валентинович \\
\hline 236 & Тодосийчук Анатолий Васильевич & 312 & Тодосийчук Анатолий Васильевич \\
\hline 237 & Кожевина Ольга Владимировна & 0 & Кожевина Ольга Владимировна \\
\hline 238 & Минаков Иван Алексеевич & 0 & Минаков Иван Алексеевич \\
\hline 239 & Красавина Лидия Николаевна & 251 & Красавина Лидия Николаевна \\
\hline 240 & Фролов Даниил Петрович & 220 & Фролов Даниил Петрович \\
\hline 241 & Маслова Влада Вячеславовна & 0 & Маслова Влада Вячеславовна \\
\hline 242 & Петров Александр Николаевич & 0 & Петров Александр Николаевич \\
\hline 243 & Козенкова Татьяна Андреевна & 126 & Козенкова Татьяна Андреевна \\
\hline 244 & Зрелов Александр Павлович & 0 & Зрелов Александр Павлович \\
\hline 245 & Якутин Юрий Васильевич & 145 & Якутин Юрий Васильевич \\
\hline 246 & Мясникова Людмила Анатольевна & 444 & Мясникова Людмила Анатольевна \\
\hline 247 & Стародубровская Ирина Викторовна & 0 & Стародубровская Ирина Викторовна \\
\hline 248 & Кучеров Илья Ильич & 0 & Кучеров Илья Ильич \\
\hline 249 & Хейфец Борис Аронович & 0 & Хейфец Борис Аронович \\
\hline 250 & Бондаренко Людмила Васильевна & 286 & Бондаренко Людмила Васильевна \\
\hline 251 & Попов Александр Иванович & 0 & Попов Александр Иванович \\
\hline 252 & Попова (Бородина) Людмила Владимировна & 0 & Попова (Бородина) Людмила Владимировна \\
\hline 253 & Якимович Борис Анатольевич & 191 & Якимович Борис Анатольевич \\
\hline 254 & Шабаева Валентина Ивановна & 184 & Шабаева Валентина Ивановна \\
\hline 255 & Гуртов Валерий Алексеевич & 182 & Гуртов Валерий Алексеевич \\
\hline 256 & Быкадоров Сергей Александрович & 0 & Быкадоров Сергей Александрович \\
\hline 257 & Каурова Ольга Валерьевна & 356 & Каурова Ольга Валерьевна \\
\hline 258 & Шишкин Сергей Владимирович & 0 & Шишкин Сергей Владимирович \\
\hline 259 & Кузьбожев Эдуард Николаевич & 196 & Кузьбожев Эдуард Николаевич \\
\hline 260 & Гумеров Рустам Раулевич & 217 & Гумеров Рустам Раулевич \\
\hline 261 & Либман Александр Михайлович & 221 & Либман Александр Михайлович \\
\hline 262 & Дадашев Алихан Заграбович & 297 & Дадашев Алихан Заграбович \\
\hline 263 & Гетьман Виктор Григорьевич & 282 & Гетьман Виктор Григорьевич \\
\hline 264 & Батьковский Александр Михайлович & 0 & Батьковский Александр Михайлович \\
\hline 265 & Климова Наталья Владимировна & 333 & Климова Наталья Владимировна \\
\hline 266 & Усенко (Голобородько) Людмила Николаевна & 0 & Усенко (Голобородько) Людмила Николаевна \\
\hline
\end{tabular}




\begin{tabular}{|c|c|c|c|}
\hline & 2016 г. & & 2015 г. \\
\hline № & Ф.и.о. & № & Ф.И.0. \\
\hline 267 & Скляров Игорь Юрьевич & 123 & Скляров Игорь Юрьевич \\
\hline 268 & Богомолова (Пахомова) Ирина Петровна & 0 & Богомолова (Пахомова) Ирина Петровна \\
\hline 269 & Баранов Сергей Владимирович & 402 & Баранов Сергей Владимирович \\
\hline 270 & Ефимова (Новодворская) Ольга Владимировна & 0 & Ефимова (Новодворская) Ольга Владимировна \\
\hline 271 & Валентей Сергей Дмитриевич & 176 & Валентей Сергей Дмитриевич \\
\hline 272 & Оболенский Владимир Петрович & 0 & Оболенский Владимир Петрович \\
\hline 273 & Синяева Инга Михайловна & 0 & Синяева Инга Михайловна \\
\hline 274 & Росовецкая Лариса Александровна & 0 & Росовецкая Лариса Александровна \\
\hline 275 & Соловьев Аркадий Константинович & 468 & Соловьев Аркадий Константинович \\
\hline 276 & Черняков Борис Абрамович & 0 & Черняков Борис Абрамович \\
\hline 277 & Катькало Валерий Сергеевич & 215 & Катькало Валерий Сергеевич \\
\hline 278 & Минервин Иосиф Георгиевич & 219 & Минервин Иосиф Георгиевич \\
\hline 279 & Карзаева Наталья Николаевна & 216 & Карзаева Наталья Николаевна \\
\hline 280 & Райков Александр Николаевич & 255 & Райков Александр Николаевич \\
\hline 281 & Клочков Владислав Валерьевич & 426 & Клочков Владислав Валерьевич \\
\hline 282 & Гайдук Владимир Иванович & 393 & Гайдук Владимир Иванович \\
\hline 283 & Якобсон Лев Ильич & 248 & Якобсон Лев Ильич \\
\hline 284 & Фридлянова (Гостева) Светлана Юрьевна & 0 & Фридлянова (Гостева) Светлана Юрьевна \\
\hline 285 & Яшина (Локтина) Марина Львовна & 0 & Яшина (Локтина) Марина Львовна \\
\hline 286 & Садков Виктор Георгиевич & 175 & Садков Виктор Георгиевич \\
\hline 287 & Зоркальцев Валерий Иванович & 0 & Зоркальцев Валерий Иванович \\
\hline 288 & Валинурова Лилия Сабиховна & 318 & Валинурова Лилия Сабиховна \\
\hline 289 & Чепуренко Александр Юльевич & 322 & Чепуренко Александр Юльевич \\
\hline 290 & Васильева Марина Владимировна & 163 & Васильева Марина Владимировна \\
\hline 291 & Громов Евгений Иванович & 125 & Громов Евгений Иванович \\
\hline 292 & Вольчик Вячеслав Витальевич & 223 & Вольчик Вячеслав Витальевич \\
\hline 293 & Городникова Наталья Валентиновна & 0 & Городникова Наталья Валентиновна \\
\hline 294 & Евстигнеев Рубен Николаевич & 0 & Евстигнеев Рубен Николаевич \\
\hline 295 & Шишкина (Рощупкина) Наталья Викторовна & 0 & Шишкина (Рощупкина) Наталья Викторовна \\
\hline 296 & Казанцев Сергей Владимирович & 0 & Казанцев Сергей Владимирович \\
\hline 297 & Мазлоев Виталий Зелимханович & 0 & Мазлоев Виталий Зелимханович \\
\hline 298 & Данько Тамара Петровна & 0 & Данько Тамара Петровна \\
\hline 299 & Кушлин Валерий Иванович & 358 & Кушлин Валерий Иванович \\
\hline 300 & Одегов Юрий Геннадьевич & 56 & Одегов Юрий Геннадьевич \\
\hline
\end{tabular}

